\title{
Cretaceous Roveacrinids from Mexico revisited: Overcoming the taxonomic misidentifications and subsequent biostratigraphic abuse
}

\author{
Bruno Ferré, Bruno Granier, Przemysław Gorzelak, Mariusz A. Salamon
}

Bruno Ferré

bruno_ferre@yahoo.fr

Dame du Lac 213, 3 rue Henri Barbusse, F-76300 Sotteville-lès-Rouen, France.

\section{Bruno Granier}

Department of Earth and Planetary Sciences, Faculty of Sciences and Techniques, University of western Brittany, 6 avenue Le Gorgeu, CS 93837, F-29238 Brest, France.

Department of Ecology and Evolutionary Biology, The University of Kansas, 1200 Sunnyside Avenue, Lawrence, Kansas 66045, U.S.A. Faculty of Sciences II, Earth and Life Sciences Department, Lebanese University, Fanar-El Matn, P.O. Box 26110217, Lebanon.

\section{Przemysław Gorzelak}

Institute of Paleobiology, Polish Academy of Sciences, Twarda 51/55, PL-00-818 Warsaw, Poland.

\section{Mariusz A. Salamon}

Faculty of Earth Sciences, University of Silesia, Będzińska 60, PL-41-200 Sosnowiec, Poland.
BOL. SOC. GEOL. MEX. 2018

VOL. 70 NO. 2

P. $499-530$

http://dx.doi.org/10.18268/BSGM2018v70n2a12

\section{ABSTRACT}

The Mesozoic carbonate deposits of Mexico yield a number of overlooked, ill-known, and even enigmatic microfossils, among which are roveacrinoids (Echinodermata, Crinoidea, Roveacrinida). Most of these pelagic organisms probably came from the central Tethysian seaways, and later on from the early central Atlantic Ocean through the northwestern Tethysian neck, thus reaching the Central American platforms (Comanchean shelf, Central Texas platform, and Coahuila platform) and the Western Interior seaway. The present work intends to enlist as comprehensively as possible the Mexican records of roveacrinid crinoids, to propose a revised interpretation of the sections illustrated (most of them being originally erroneously assigned) and to provide a sound data base for further systematic and biostratigraphic research.

Keywords: Echinodermata, Grinoidea, Roveacrinida, Gre taceous, Microfacies, Mexico.

\section{RESUMEN}

Los depósitos carbonatados mesozoicos de México ofrecen una gran cantidad de microfósiles que no han sido objeto de la atención merecida, por ello están mal conocidos y algunos de ellos son aún enigmáticos, entre estos microfósiles se encuentran los roveacrínidos (Echinodermata, Crinoidea, Roveacrinida). La mayoría de estos organismos pelágicos probablemente provenian de los corredores del tetis central y después de la parte media de un primitivo océano Atlántico y a través del corredor noroeste del tetis, llegaron a las plataformas de América Central (Plataforma de Comanche, Plataforma de Texas Central, Plataforma de Coahuila) y el Mar Interior Occidental. Esta publicación pretende enlistar con el mayor detalle posible los registros mexicanos de crinoideos roveacrínidos, proponer una nueva interpretación de las secciones ilustradas (generalmente erróneamente asignadas) y proporcionar una base de datos sólida para poder realizar investigaciones más detalladas de su sistemática y bioestratigrafia.

Palabras clave: Echinodermata, Crinoidea, Roveacrinida, Cre tácico, Microfacies, México. 


\section{Introduction}

During the last three decades, the MidCretaceous ocean of northern Mexico has been the focus of intense and diversified geological interpretations that were initiated with the UNESCO International Geological Correlation Program - IGCP 381 "South Atlantic Mesozoic Correlations". This area has been subdivided into a number of wide depressions, basins, swells and platforms, all inherited from large tectonic units in the Triassic that partially continued to exist during the Jurassic as continental blocks. Meanwhile, evaporites were being deposited during the Late Triassic and Jurassic in the Gulf of Mexico that served as a great evaporating basin in which brines derived from the Atlantic Ocean seawater were concentrating. After intense halokinesis of Triassic salts and general subsidence initiated in the Jurassic, this whole area was the scene of a homogeneous ocean in Early Cretaceous times. During this period, northern Mexico was located at the marine crossroad between the eastern central Tethys and the Pacific Ocean, the Western Interior Sea and the Paleo-Andean corridor, with widespread rudistid-bioconstructions rimming the shelf margins (Scott et al., 2016). Such a paleogeographic location favoured pelagic biodiversity by means of productivity enhancement and overdrive of ecological niches. Along with an abundance of nannofossil and dinoflagellate microfossils, a few prominent microfacies taxa of echinodermal affinity diversified and have been used to subdivide the stratigraphy of the Upper Tamaulipas Formation (Fm.; Bonet, 1956; Trejo, 1975, 1981, 1983). Recently, some other related crinoidal microfacies have been found in abundance; however their use as stratigraphic markers requires a systematic revision of formerly reported sections.

The present work intends to enlist as comprehensively as possible the Mexican records of roveacrinid crinoids, propose a revised interpretation of the sections illustrated (most of them being originally erroneously assigned), and provide a sound data base for further systematic and biostratigraphic research (e.g., geological mapping efforts, oil industry exploration).

\section{Morphology, Petrogenetics, Palaeoecology and Systematics}

\subsection{ANATOMY}

Since discarded or accumulated roveacrinid remains are not easily spotted in the field and are therefore studied under a petrographic microscope and/or SEM (Scanning Electron Microscopy), they are usually mentioned as microcrinoids or misinterpreted as planktonic crinoids (instead of pelagic). The thecal size does not exceed a few millimetres; a complete specimen is about $5 \mathrm{~cm}$ wide. Roveacrinids are small articulate crinoids with five dichotomous arms, each displaying many brachial plates (up to three dozen in complete specimens). Their minute theca is devoid of any stem or anchoring device, and is built of two sets of plates, basal and dorsal, sometimes showing a prominent centrodorsal bulge. When exceptionally preserved, it displays an inner plate ring defining a double body cavity (Schneider, 1987, 1989). Each roveacrinid species displays a distinctive architecture and widely different ornamental elements, such as a spine-like aboral element, simple bowls with or without processes, flanged or winged brachials, lateral processes, and flanges or spines (e.g., Schneider, 1987, 1989; Jagt, 1999; Hess, 2015; Gale, 2016). Figure 1 depicts a synthetic diagram of a complete roveacrinid individual.

These small, mostly pelagic, crinoids are first reported after the Permian-Triassic Boundary event of the Tethys realm (Salamon et al., 2015). Since then, the pelagic roveacrinids experienced several periods of extensive radiation (Gorzelak et al., 2016) that might coincide with some diversification and abundance phases of calcareous phytoplankton. Their early planktonic larval stage as many open-marine organisms and their massive occurrence, partly explain their opportunistic standing and paleogeographic dissemination 
through the Tethysian seaways and corridors. They are also valuable to indicate high-productivity event beds (and also subsequently hypoxic-anoxic events, sensu Schlanger and Jenkyns, 1976).

\subsection{PETROGENETIG GONTRIBUTION}

Goldfuss (1826-1844) reported complete articulated roveacrinids ("Saccocoma" auct.) from the Tithonian platy limestones of southern Germany, which have become famous worldwide. Because their disarticulated remains are inconspicuous but they are very abundant in Jurassic marls, specific recognition of isolated plates was only achieved through the pioneering studies of Verniory (1954, 1955, 1956, 1960, 1961, 1962). Meanwhile the stratigraphic value of roveacrinidal microfacies was made noteworthy by Brönnimann (1955).
The genuine roveacrinoidal contribution to the Mesozoic (Jurassic) limestones was first mentioned in Verniory's seminal works (ibidem), and later only evoked in various articles (i.e., Lombard, 1937, 1945; Brönnimann, 1955; Bengtson and Berthou, 1983; Berthou and Bengtson, 1988; Dias-Brito, 1994, 1995; Dias-Brito and Ferré, 1997, 2001; Benzaggagh et al., 2015).

Roveacrinids within worldwide Mid-Cretaceous carbonate research were only rarely mentioned in the literature ("Saccocoma" limestones auct.) and ignored by overspecialized palaeontologists, or simply turned down by oil industry engineers.

As for microfacies analysis, the roveacrinidal affinity of some Cretaceous sections was originally reported by Ferré and Berthou (1993, 1994). At the same time, they provided a morphological 3D-reconstruction of a whole individual from

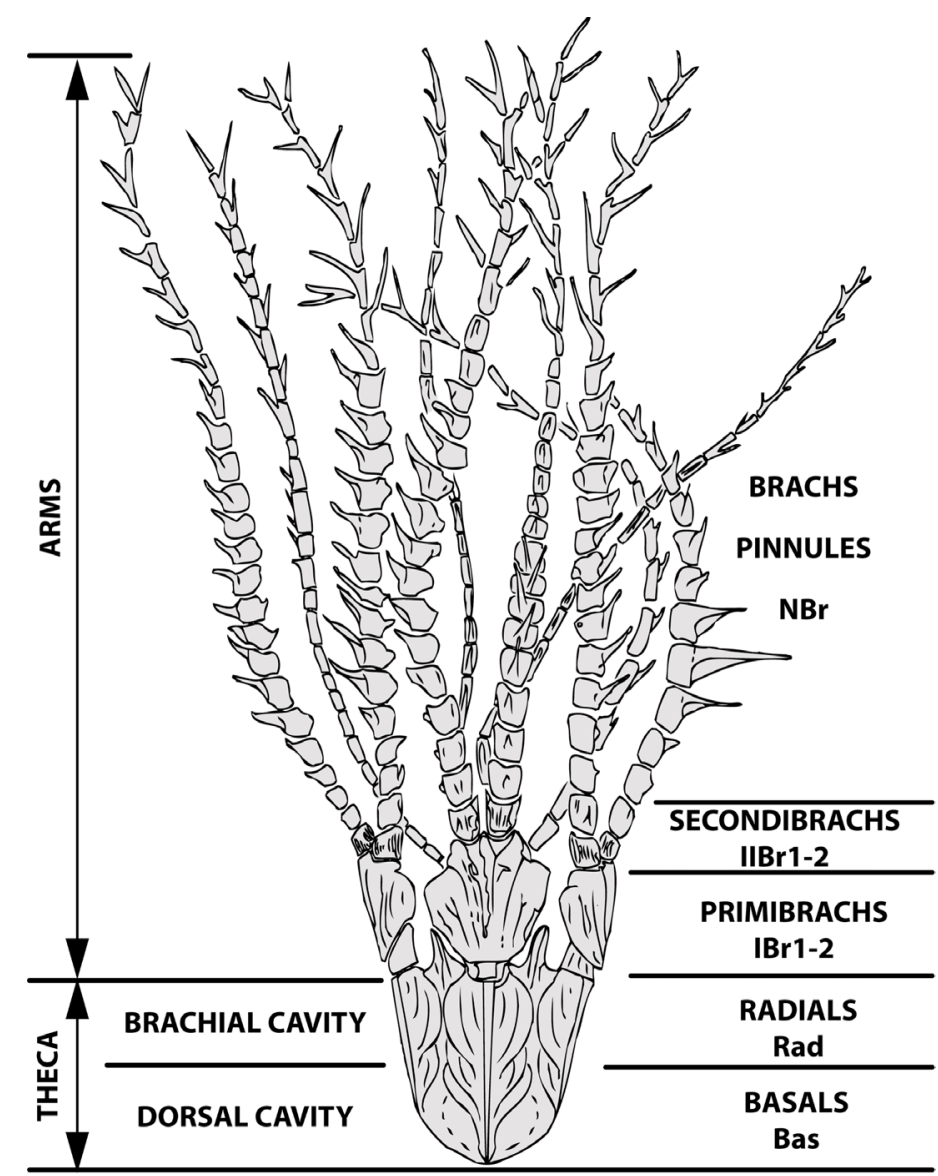

Figure 1 Tentative reconstitution of a complete roveacrinid individual (namely Roveacrinus geinitzi SCHNEIDER, from Ferré and Berthou, 1994). 
various sections and diverse section planes, and coined the formal terminology for section orientation. Limited at first to roveacrinids, the section orientation scheme was then extended to saccocomids (Ferré and Dias-Brito, 1999). Meanwhile, Ferré and Granier $(1997,2001)$ defined at length the orientation and taxonomic use of roveacrinid sections. Following that, the systematic assignment of Cretaceous roveacrinid sections was fully debated for both the roveacrinids and the saccocomids (Ferré, 1997; Ferré et al., 1999; see Figure 2).

\subsection{SUSPECTED EGOLOGY}

As with any echinoderm and many other oceanic groups, the first stage of roveacrinid life is planktonic, allowing wide passive dispersal by marine currents. Though the planktonic character of the adult and gerontic forms has not been fully substantiated, they are pelagic organisms. As adult life forms, they are found in pelagic and hemipelagic sediments, in outer carbonate shelves (outer-shelf and upper-slope environments) and outer neritic environments. As far as their arm structure is concerned, they were likely capable of temporary active swimming to escape predators (e.g. most likely slow moving benthic predators; Baumiller et al., 2010; Gorzelak et al., 2012). However, they were not that swift since some of their brachial plates can be found in bromalites (i.e., Lumbricaria). Every element of their delicate skeleton facilitates floating or support on softground, upgrades

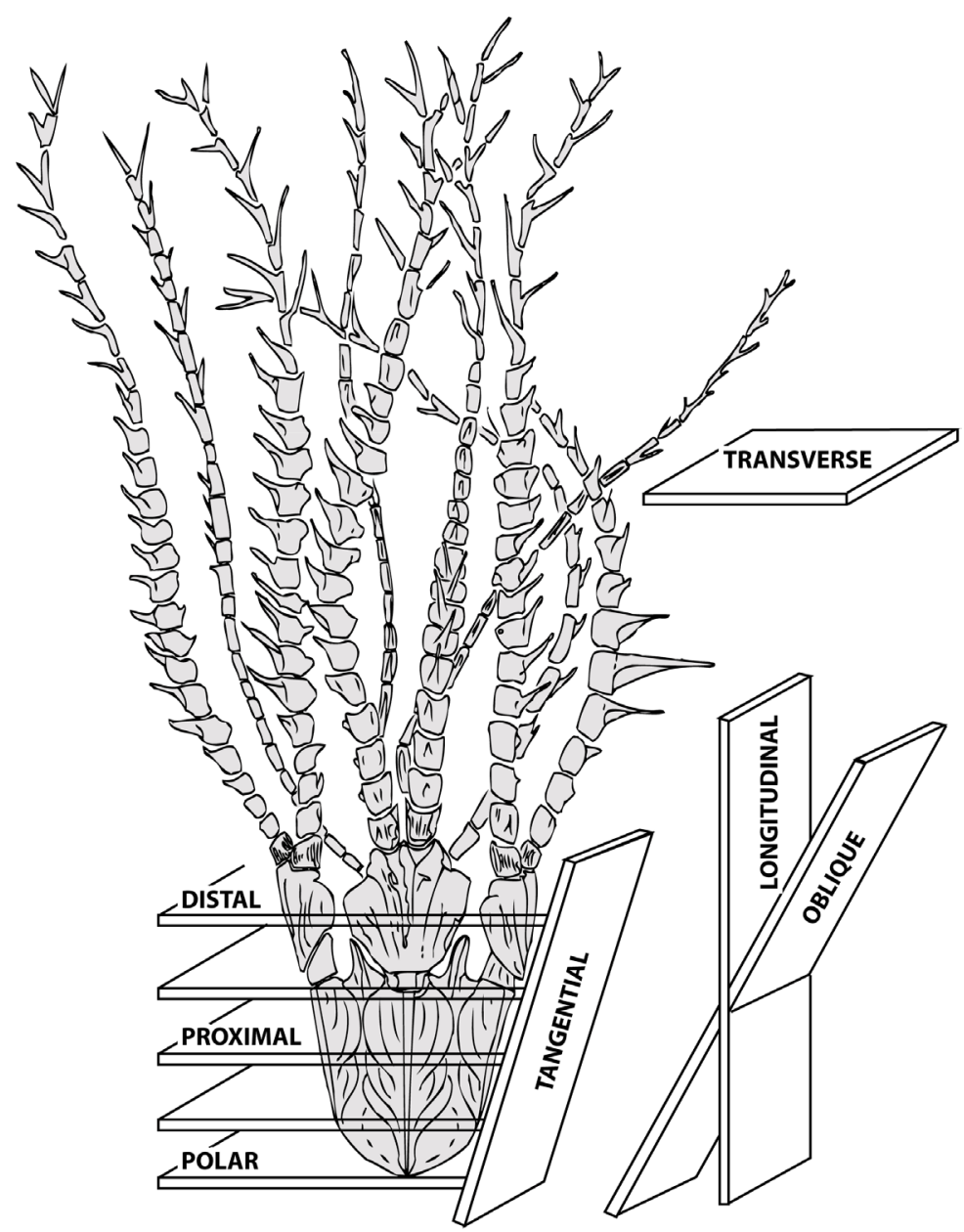

Figure 2 Terminology and orientation of the main thin-section planes in a roveacrinid individual as could be observed in microfacies (from Ferré and Berthou, 1994). 
basket-net feeding and enhances defence against or the repelling of predators.

Usually conspicuous in washing residues of finegrained pelagic facies, along with common opportunistic microfossils (calciodinoflagellate cysts = calcispheres, foraminifers, ostracodes, etc.) but without classical index markers, roveacrinids are generally overlooked by experienced but incurious palaeontologists, but are always puzzling openminded keen microbiostratigraphers.

From the rather limited number of papers mentioning their existence, that particular crinoidal component appears to be mostly composed of opportunistic roveacrinids responsible for these very special microfacies scattering.

For saccocomids, Milsom (1989) advocated for a benthic "snow-shoe" way of life. As for other relatives, they are suspected of being active swimmers filtering the sedimentary planktonic pelagic snow in some schools of feeding crinoids. However, they look merely much like active filter-feeders hidden in the bottom current flows (planktonic larvae, organic cysts, pellets, etc.), like any comatulid, passively resting most of their time on the sea bottom with their arm basket wide open (Ferré and Bengtson, 1997; rehearsed in Souza-Lima and de Castro Manso, 2000) and capable of fleeing predator attacks by swift active swimming and escape contractions. As opportunistic filter-feeders, they thrive during high sea-level stands and high-productivity times; their abundance horizons underline flooding surfaces and transgressive system tracts (Ferré et al., 2005), making them first-grade litho-, bio-, event- and sequence-stratigraphic markers.

\subsection{SYSTEMATICS}

The suprageneric systematics follows the classification of the Treatise (Hess and Messing, 2011). As recorded in this updated version, the order Roveacrinida consists of 4 families:

a) Axicrinidae (monogeneric), from the Triassic deposits of central Tethys; b) Somphocrinidae, from early Triassic (Dienerian-Griesbachian: Salamon et al., 2015) to Late Triassic (Kozur and Mostler, 1971; Donofrio and Mostler, 1975; KristanTollman, 1975, 1977, 1991; Hess et al., 2016), ranging mostly over the whole Tethysian Ocean and further north to the Svalbard archipelago, with a special emphasis on the first described member, Somphocrinus mexicanus PECK, 1948, from Mexico (Peck, 1948);

c) Saccocomidae, from Jurassic (for review see Hess, 2002) to early Maastrichtian (Jagt, 1999) with a special emphasis on the SantonianCampanian boundary (Gale, 2016);

d) Roveacrinidae, from early Hauterivian of Spain (Ferré and Granier, 2000) to Late Cretaceous of Boreal Europe (Jagt, 1999; Hess, 2015; Ferré et al., 2016a; Gale, 2016, 2017), with "inconsistent" records beyond (Paleogene-Neogene of Poland; Salamon et al., 2010; Gorzelak et al., 2011).

\section{Microfacial studies}

\subsection{GENERAL IN-FIELD PRACTICE}

Since they are not easily detected by field collectors (except for their rock-building abundance of brachial plates), and they are studied under a petrographic microscope and/or through SEM, roveacrinoids are sometimes mentioned as microcrinoids (maximum thecal size of a few millimetres).

Complete articulated roveacrinids ("Saccocoma" auct.) have been known from the Tithonian platy limestones of southern Germany since Goldfuss (1826-1844). Thus far complete individuals of Cretaceous roveacrinoids can be counted on the fingers of one paleontologist's hand (Scott et al., 1977; Ferré and Bengtson, 1997; Ferré, personal data).

Their minute disarticulated remains are inconspicuous and are hardly noticed during field 
research. Fortunately, their abundance provides an obvious petrogenetic contribution to Jurassic deposits (Verniory, ibidem). Brönnimann (1955) considered them as potential stratigraphical indicators based on microfacies analysis. Likewise, Ferré and Berthou (1993, 1994), and Ferré and Granier (1997) applied such a methodology to the Cretaceous microfacies of Brazil and its Angolese counterpart.

Obviously frequent in washing residues of pelagic facies (outer neritic and outer-shelf environments), they are highlighted by default since the standard classical microfossil groups (foraminifers, ostracodes, etc.) are simply missing.

\subsection{BRIEF HISTORICAL REVIEW OF ROVEACRINOIDAL STUDIES}

The first illustration recorded to date ever confidently assignable to roveacrinoids comes from Hanns Bruno Geinitz (1871), who illustrated a genuine roveacrinid theca as an Aristotle's lantern. More than a hundred years later, this original material became the holotype of Roveacrinus geinitzi Schneider (Schneider, 1989; Niebuhr and Ferré, 2016). At the turn of the $20^{\text {th }}$ century, while tackling the English Chalk stratigraphy by means of Micraster lineages, Arthur Rowe retrieved eccentric ossicles from washed Sussex "flint meal" (i.e., soft chalk cores of hollow flints): this original material was then first formally described (and subsequently dedicated to their discoverer) as Roveacrinus by Douglas (1908). Peck (1943, 1948) extensively traced their stratigraphic range through the Cretaceous (Albian-Cenomanian) of the U.S. Gulf States and in the Triassic of Mexico, and enhanced their potential stratigraphic value. Rasmussen (1961) compiled an updated knowledge of roveacrinid systematics. While investigating the Lower Cretaceous deposits of Cuba, Bonet (1956) described quite a number of original microfossils among which are calcispheres, and the genus Microcalamoides (as incertae sedis). This later unrelated genus was then extensively used in Mexican stratigraphy to define a biozone straddling the Aptian-Albian boundary. This microfacies genus was later assigned to saccocomids (Ferré and Dias-Brito, 1997). By defining a new Tethysian carbonate microfacies ("Osteocrinusfazies"), Kristan-Tollmann extended the knowledge of these crinoids back to the Triassic of Austria (1975, 1977) and farther east to Iran (1991). Likewise, though often occurring in masses in Cretaceous deposits and rock-building carbonate microfacies, this wealth of microfacies data is turned down by collecting palaeontologists who prefer complete third-dimensional specimens to tackling their mental agility with the relative complexity of their microfacial-morphological features.

\section{3. "GONTROVERSIES"}

Whether isolated from the rock (and sometimes badly preserved or frequently harmed during the extraction process from the indurated rock) or evidenced in thin sections, any ossicle tentatively assigned to the order Roveacrinida is subject to careful consideration. Even currently their study by means of microfacies remains confidential to some authors, and all Chinese, who favour nearly complete specimens. Unfortunately, such an analytical restriction hampers the opportunity of filling some of the numerous stratigraphic gaps in their fossil record.

Regardless of their ontogeny, relatives of the order Roveacrinida are termed "microcrinoids" since their study requires the use of binoculars. Their origin is still questionable but is believed to have occurred with the Permian crinoids.

Recently roveacrinidal remains (within related somphocrinid- and Osteocrinus-microfacies) have been found in the Induan Vardebukta Fm. of Svalbard (Salamon et al., 2015), indicating that they first "appeared" after the Permian-Triassic Boundary event of the Tethys realm.

After the Permian-Triassic boundary, the pelagic roveacrinoids experienced several periods of extensive radiations that might coincide with some diversification and abundance phases of calcareous phytoplankton. However, we must keep in mind that this "positive" correlation is more a guess than a ground truth; their stratigraphic 
record is far from complete: they are best-known in the Middle Triassic, in the middle and Late Tithonian (before the $\mathrm{J} / \mathrm{K}$ boundary), and in the Albian-Cenomanian, Santonian-Campanian and Maastrichtian for Cretaceous times. As for their extinction, which is in need of further investigation, there are isolated records in the Neogene of Poland (Salamon et al., 2010; Gorzelak et al., 2011), which have reopened the debate of their survival past the K/T boundary.

Each roveacrinoid relative displays a distinctive architecture and widely different ornamental elements, such as a spine-like aboral element, simple bowls with or without processes, flanged or winged brachial plates, lateral processes, flanges or spines (e.g., Schneider, 1987, 1989; Gale, 2016). Every element of their delicate skeleton facilitates floating or helps support them on a soft-ground substrate. Consideration of such ornamental elements can help reconstruct the paleoenvironment and sea bottom hydrodynamics. With this in mind, the position of roveacrinoids in the water column is still debatable: the most parsimonious interpretation envisions the adult stage of these organisms as pelagic benthonics, passively filter-feeding in the current flow, and with reduced lift-off capability to escape predatory pressure.

\section{Plate recognition and identification of thin sections}

Following the revision of the Mid-Cretaceous carbonate microfacies of the Sergipe basin (Bengtson and Berthou, 1983; Berthou and Bengtson, 1988), Ferré and Berthou (1993, 1994) first introduced formal recognition of roveacrinid microfacies and coined the general identification frame in thin section. Later on, this was further refined and upgraded into a detailed plate-focused panel (Ferré and Granier, 1997). The general orientation and taxonomic value of such roveacrinidal sections were then given in Ferré and Granier (2001) as a definitive issue. Moreover, some particular microfacies sections, widely used for local biozonation (i.e., Microcalamoides Bonet, 1956), were synonymized and revised (Ferré, 1997). Noteworthy is the common occurrence of Microcalamoides Bonet, 1956 roughly defining the Microcalamoides Zone (around the Aptian-Albian boundary) of the Upper Tamaulipas Fm. in Mexico (see comments below). Figure 2 illustrates the main terminology of thin-section plane orientation within a roveacrinidal skeleton, from the basal plates of the calyx (Bas/Rad) to the last tertibrachial plates (NBrn) of the five dichotomous arms.

\section{Revised description of the Mexican roveacrinoids and subsequent implications}

Historically, the first report of roveacrinoids from the Gulf of Mexico (Mexico and southern USA) is due to the thorough stratigraphic range records made during the mapping efforts of Peck (1943). Shortly after, Peck (1948) erected Somphocrinus mexicanus on original material from the Carnian deposits of Mexico, which remains the only Triassic occurrence of roveacrinoids in the far western Tethys, unlike the relative abundance of somphocrinids in central Tethys as described by Kristan-Tollman (1975) under the term "Osteocrinusfazies", and further extended (Austria: Mostler, 1972; Donofrio and Mostler, 1975; Kristan-Tollmann, in KristanTollmann and Krystyn, 1975; Kristan-Tollmann, 1977; Kristan-Tollmann and Tollmann, 1981) to the eastern part of Tethys (the early Carnian of Turkey and latest Ladinian of Iran; KristanTollmann, 1991).

During the Jurassic, though worldwide famous, the only available Mexican references of roveacrinoids are the stratigraphic and paleoenvironmental reports of Aguilera-Franco and Franco-Navarrete (1995) concerning the Mid-Tithonian occurrence of some "Saccocoma Arachnoidea (Brönnimann, 

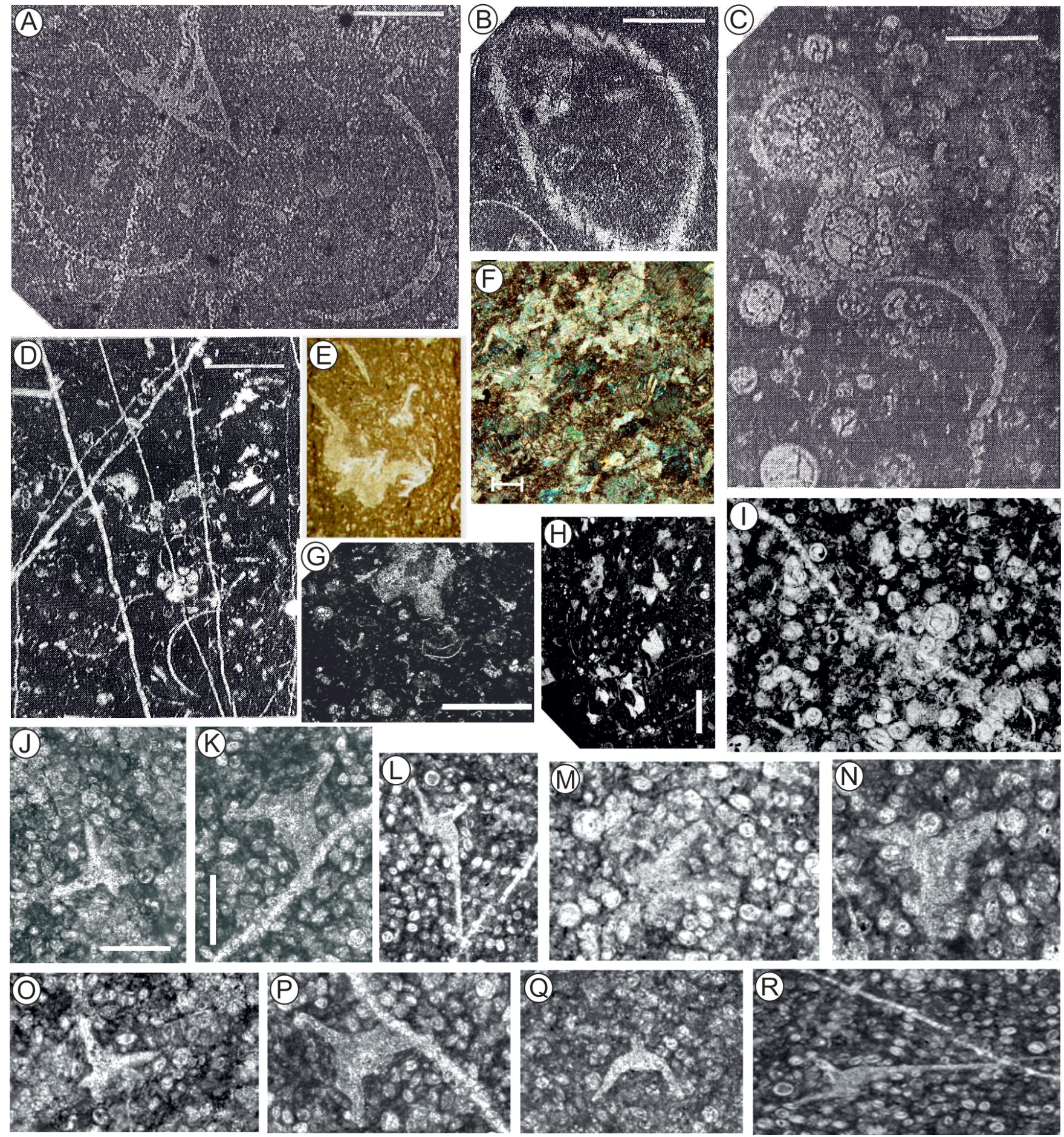

Figure 3 Re-interpretation of previously illustrated roveacrinids. Abbreviations used: Ax, axial; Lg, longitudinal; Obl, oblique; S, section; T, transverse; Tg, tangential. Rad, radial plate (or theca), IBr, primibrachial plate; IIBr, secundibrachial plate, NBrn, distal/indeterminate brachial plate. For revised taxonomic assignment and detailed stratigraphical assignment, see Appendix $\mathrm{C}$. 
1955)" [actually oblique-transverse sections of primi- and secundi-brachial plates (Obl/Ts-IIIBrn) of Saccocoma tenella (Goldfuss)].

In their taphonomic survey of the Jurassic/ Cretaceous boundary carbonates from nearby western Cuba, López-Martínez et al. (2014) illustrated a "highly disarticulated and densely packed Soccocomids" [sic!] (figure 3E: 436). They interpreted the abundance levels associated with calpionellid blooms as the sudden development of deep environmental, pelagic conditions, and suggested their auto-allochthonous origin (moderate transportation from the original drowning platform) by the "high disarticulation degree, orientation of many Saccocoma arms fragments, high fragmentation index, and the accumulation of coarse debris" (ibidem: 437). Furthermore they lament that the taphonomical conditions of Saccocoma event beds hamper any interpretation of paleo-community indices due to the high replication and redundancy of saccocomids. However they consider that saccocomids are a key constituent of the paleo-community, since saccocomids are pioneering organisms, colonizing new ecological niches after the carbonate bank drowning.

On the whole, the extensive record of saccocomids in the Jurassic carbonate rocks of Mexico have never been successfully exploited for stratigraphic purposes, unlike in the European Alpine areas. Nevertheless, saccocomids is often used incorrectly both in academic and internal reports of the oil industry concerning the Mexican stratigraphy.

The present paper aims to restore the straightforward use of saccocomids (in a broader sense, as pelagic crinoids) in the micropaleontology and stratigraphy of Mexico.

\subsection{ALBIAN MICROFAGIES GUIDELINE: THE MicRoCALAMOIDES GONTROVERSY}

In the late 1950s, F. Bonet analyzed the Cretaceous successions of Cuba and described a large number of new microfossils of undefined affinity. Among them, the genus Microcalamoides BONET, with three species (Bonet, 1956; O'Neill and Waite, 1969; Trejo, 1975, 1981, 1983, in Trejo and Bautista, 1977; Enos and Stephens, 1993; RosalesDomínguez et al., 1995), which were also extensively recovered in the (Aptian?-) Albian deposits of Mexico (and the U.S.A., see McNulty, 1985; Enos and Stephens, 1993) and used to describe a microfacial biozone, the Microcalamoides Zone. While reviewing the multiple look-alike roveacrinidal sections, Ferré (1997) came to the conclusion that Microcalamoides was a microfacial equivalent of some Applinocrinus thecal sections and subsequently a junior synonym of genus Applinocrinus. Therefore, we are facing a paradoxical situation: from a Systematics point of view, we must now use the generic appellation Applinocrinus for such sections; from a stratigraphic point of view, the historical "Microcalamoides Zone" has priority for vernacular usage (though it is incorrect).

In the last decade, some saccocomid sections, said to contain the classical Microcalamoides microfacies, were mentioned from the Albian-Cenomanian of the Coahuila block (NE-Mexico) during public conferences. These sections were discussed informally afterwards, but these presentations and discussions were never published (Gréselle et al., 2009, 2010).

While investigating the microfacial stratigraphic potentials of the Barremian-Albian interval of the state of Durango, Núñez-Useche and Barragán (2012) coined a term Microfacies Association MA-17, said to contain "abundant saccocomids and plates of crinoids" [sic.]. The presence of microcalamoids in the La Peña and the Upper Tamaulipas Fms is also mentioned (figures 7b - 7c in Núñez-Useche and Barragán, 2012: 210211). In their following discussion, these alleged saccocomids turned into Saccocoma spp. in MA-17 (ibidem: 215). Unfortunately, the blunt and massive crinoid plates indeed belong to stemmed crinoids (most probably bourgueticrinids). In their figure $7 \mathrm{a}$ (ibidem: 212) "the largest bioclast" does not "correspond to a brachial element of Saccocoma sp."; but instead belongs to a stemmed crinoid (sample PFZ533). However, there is a genuine rather 
"smooth" thecal section of saccocomid above this largest one: Applinocrinus sp. (ex Microcalamoides sp.). The alignment of crinoidal plates in their figure $7 \mathrm{~b}$ (ibidem: 212) is effective and corresponds to the dismantling of an arm fragment (stemmed crinoid), with some minute sections of saccocomid brachial plates (sample PFZ613). Their figure 7c (ibidem: 212) only illustrates the honeycomb structure of a tangential transverse section of an inoceramid shell while their figure 7d (ibidem: 212) illustrating a "Wackestone with calcispheres and ostracods" (ibidem: 212) also yields a couple of minute saccocomid brachial sections (sample PFZ582). As far as dating is concerned, their figure 2 (ibidem: 207) indicates "Saccocomids" in the last $20 \mathrm{~m}$ of the La Peña Fm., but does not show any in the above Upper Tamaulipas Fm. Furthermore the presence of Favusella sp. in their MA-17 indicates a Late Albian age.

A series of new microfacies sections and localities discussing these "microproblematics" will be described in detail soon from the Albian deposits of Sierra Azul, Coahuila (Monier-Castillo et al., 2017a, 2017b).

Currently the only known single complete specimen of a roveacrinoid is Roveacrinus spinosus PECK from the Sergipe basin, Brazil (Ferré and Bengtson, 1997), and the only few Cretaceous roveacrinid ossicles still in connection were described by Scott et al. (1977) from the Albian deposits (Weno Fm.) of Texas. In addition, some complete connected specimens of Roveacrinidae from the Lower Cretaceous deposits were recently found in museum collections and in a field search (Ferré, personal data).

\subsection{THE GENOMANIAN-TURONIAN INDEX LEVELS: TOWARDS THE G/T BOUNDARY POSITIONING}

While studying the Mesozoic deposits of Sierra La Nieve (Coahuila, NE Mexico), Longoria and Monreal (1991) illustrated two sections of Microcalamoides diversus BONET and, following Bonet's first suggestions, interpreted such sections as ostracod shell or brachiopod valve sections.
At the 1997 Heidelberg meeting (18th Symposium of the International Association of Sedimentologists, Regional Meeting of IGCP Project 381 "South Atlantic Mesozoic Correlations" and Second European Meeting on the Paleontology and Stratigraphy of South America, Heidelberg, Germany, Sept. 2-4, 1997), Noemi Aguilera-Franco's poster presented some echinodermal sections that were on that occasion identified as roveacrinoids and identified down to the specific level (Aguilera-Franco et al., 1997, 2001; Aguilera-Franco, in Hernández-Romano et al., 1997). This became the first formal report of indigenous Mexican roveacrinids around the $\mathrm{C} / \mathrm{T}$ boundary ever published (Aguilera-Franco, 1995, 2003; Aguilera-Franco et al., 1997, 2001).

In their stratigraphic and sedimentological analysis of CSDP drill-core Yaxcopoil-1, Stinnesbeck et al. (2004) reported the occurrence of rare pelagic crinoids in the Cenomanian core deposits. They illustrated a section of a "planktic crinoid" [sic!, figure 3.1: 1046] from the Uppermost Cenomanian (Unit B, sample 1851). The associated foraminiferal assemblage (Whiteinella archaeocretacea, W. baltica, Rotalipora cushmani, R. greenhornensis, and Hedbergella spp.) precisely marks the top of the Rotalipora cushmani TRZ. Noteworthy is the joint occurrence of "rare pelagic crinoids, filaments, and calcispheres" as a faint sign of hypoxic environment typical of OAE2 (but not sufficient to tell which side of the $\mathrm{C} / \mathrm{TB}$ ). However their figure 3.1 (Stinnesbeck et al., 2004: 1046) actually illustrates an oblique/ tangential section of a complete theca $(\mathrm{Obl} / \mathrm{TgS}-$ Theca) of Roveacrinus alatus DOUGLAS.

Omaña et al. (2014) observed roveacrinid remains from calcisphere-rich, packstone-wackestone carbonates (Microfacies 3: 32) of the Archaeocretacea Partial Range Zone (that is, Latest Cenomanian) and illustrated these indeterminate plates and sections (roveacrinids: figures 5h, i: 34 ).

More recently, Buitrón-Sánchez and OmañaPulido (2014, 2015) tentatively assigned roveacrinid remains to the Cenomanian-Turonian deposits of Cerritos (west of the Valles-San Luis Potosí Platform). Unfortunately, despite the standard 
microfossil events correlatable to OAE2, the foraminiferal assemblage [Muricohedbergella delrioensis (CARSEY), M. planispira (TAPPAN), Heterohelix moremani (CUSHMAN), H. reussi (CUSHMAN), Whiteinella archaeocretacea PESSAGNO, W. aprica (LOEBLICH and TAPPAN), $W$. brittonensis (LOEBLICH and TAPPAN), W. baltica DOUGLAS and RANKIN, and $W$. paradubia (SIGAL)] only permits assignation of their occurrences to the Latest Cenomanian. Besides, the absence of Helvetoglobotruncana praehelvetica (TRUJILLO), and most importantly of $H$. helvetica (BOLLI), supports the Latest Cenomanian determination. With respect to the plate and the specific identification, the taxonomical assignments are flawed due to superficial comparison to European taxa (see Appendix A herein) and must be revised for further taxonomical and stratigraphic purposes (see Appendices A and B herein). In addition, most of the roveacrinidal information gathered from the published literature is not well supported due to flaws of confusion.

More recently Hess (2015) and Gale (2016) provided additional insights on loose roveacrinoid materials from the Albian-Cenomanian deposits of Texas and the Santonian-Campanian U.S. Gulf Coast respectively.

\subsection{THE LATE GRETAGEOUS EXPECTATIONS}

Thus far, no roveacrinoidal microfacies, or anything similar, have ever been found or reported from the Upper Cretaceous of Mexico. It is most unlikely that they are absent since Peck (1973) reported that the distribution of Applinocrinus in North America; and uintacrinids, marsupitids, and similar chalk associated macrofossils, are well known from deposits in southern Texas.

Such an absence may be due to the lack of knowledge of such remains, both in microfacies and in loose washing residues, and to the field paleontology format of the academe teaching that primarily focuses on "first-order" microfossil groups and general fossil index.

\section{Paleoenvironmental proxies and hypoxic events (OAEs)}

Due to built-in magnesium calcite, the roveacrinoidal plates are rather resistant to weathering, leaching and erosion but are prone to bio-erosion (microbial and microborers) and fading with general recrystallization through diagenesis. Therefore, in microfacies, their sections are easily preserved and readily observable. However the disarticulation pattern of the isolated roveacrinoid ossicles, the relative state of preservation, and the shape of ossicles (preservation of ornamental elements) can help to reconstruct their relative transport after death: from autochthonous deposition (complete specimens or large individual fragments) to parautochthonous (cluster of ossicles still connected) to allochthonous (isolated ossicles scattered within the microfacies). Actually, the roveacrinoidal plates are not interlocked. Consequently, soon after death, the skeleton is swept away by bottom currents and the whole skeleton decays and crumbles into fragments that may either be transported or locally dismantled before final burial.

Besides transportation, their abundant concentration in a certain level or their regular presence in a carbonate bed set document a relative productivity level, given their alleged feeding on "pelagic snow" or bottom current filtering/screening, and their association with nannofossil blooms (nannofossils, calcispheres and organic dinoflagellate cysts, heterohelicidids, pellets, etc.). Besides revealing key flooding surfaces and/or relative high sea-levels, such abundance levels of roveacrinoid clasts represent a faint sign of hypoxic environments in which those pelagic organisms which were bottom dwellers of mud/fine-grain supported bottoms (lagoonal conditions) and pseudo-reefal hideaways (from upper dynamic tidal bar to open-shelf marine sediments) had been thriving.

As for any echinoderm brood or juvenile (and many marine organisms), their revealed widespread 
paleogeographic distribution and global (at least central Tethysian-wide) dispersal merely reflect their early planktonic stage. Whether they once had a stem (and therefore fixed benthic bugs) and later lost it, or were devoid of any anchoring device from their very early bloom, is another story (not documented so far). However, the crossroad between the central Tethysian seaway, the Western Interior Sea, and the Paleo-Andean corridor easily explains their presence in such high numbers, especially during OAEs. These anoxic-hypoxic events have been focusing much of the attention of stratigraphers: Therefore most of the roveacrinoidal literature records we found address the Aptian-Albian boundary (OAE1b), referred to as the Microcalamoides Zone, and around the Cenomanian-Turonian boundary (OAE2). In such a context the lack of Coniacian-Santonian roveacrinoid record (OAE3) is most intriguing. These roveacrinoid debris levels can be interpreted as among the first stirrings of surface productivity and a hypoxic bottom environment.

\section{Bio-stratigraphic potentials}

Roveacrinoidal remains were on the whole ignored or clumsily evoked during working sessions of international congresses and symposia. Classically, in Mexico, thanks to the seminal works of Bonet (1956) and Trejo (1975, 1981, 1983, in Trejo and Bautista, 1977), the abundance of saccocomids around the Aptian-Albian was used by field geologists and stratigraphers to build the Microcalamoides Zone. Unfortunately, these remains are also occurring to a lesser extent below and above this abundance zone. This situation is rather confusing since this zone is generally understood and considered as a Total Range Zone (instead of an Abundance Range Zone) and its taxonomical assignment/reference is not outdated (Ferré et al., 1999). However, the mere reporting of such 'bioclastic' component is most valuable and contributes towards its further use in a synthetic comprehension of their geographic extension and stratigraphic range.

Consequently, if not compiled outside any other event time frame, their abundance levels must be considered with extreme caution since the fossil blooms they represent occur as sometimes conspicuous, sometimes faint, flooding levels in transgressive tracts and can be easily confused with another from the next transgressive trend. Within this respect, qualitative range has not been effective, though the reported levels are susceptible to exploitation on a biostratigraphic level [likewise the southern England biozonation of Gale (2016, 2017)] since macrofossil zonation is rather loose and positioning any boundary remains rather difficult (the rule of hypoxia over these periods made the coeval respective environment adverse for datation-supporting macro- and micro-fossils). Meanwhile the semi-quantitative analysis of their microfacies occurrence is sometimes flawed by taxonomical laxness or inexactitude (see above with concerns on the assignment of Microcalamoides). However, when macrofossil data are lacking and standard microfossil datation is loose, they may give interesting hints for positive correlations, both locally and regionally, and could be in the near future framed into a tentative biozonation similar to that of the Sergipe Basin (Ferré et al., 1996) or to the seminal tentative record of Peck $(1943,1955)$. The main problem is the uncomfortable silence of field geologists when they find such echinoderm abundance levels (numerous elusive citations in grey in-house publications), and the confidentiality required by the economic significance for Oil Companies themselves complaining about the lack of stratigraphic precisions (the debate has come in full circle).

These "event" and accumulation beds have potential as field marker beds, for at least regional, and even Tethysian-wider long distance correlation. Meanwhile this underrated fossil group provides potential fossil guides (both in the field and in the lab) to the detection of even minor ecological disturbances and the constraint of some key crises. 


\section{Conclusions}

In the Cretaceous Tethysian deposits around the world, roveacrinoidal microfacies have proven to be an excellent field guide for stratigraphic exploration, useful to the determination of special index horizons and provide first-hand material to document crinoid biodiversity.

We have to recognize the pioneering stratigraphic masterpiece of Bonet (1956) who first highlighted the potential stratigraphic use of Microcalamoides in Cuba and brilliantly introduced the Microcalamoides Zone into the Mexican stratigraphical Lexicon (Bonet, 1956; Trejo, 1975; Trejo-Bautista, 1977).

The field stratigraphic value of Microcalamoides is indisputable. Nevertheless we must take a fresh look at its taxonomic assignment and reconsider its possible biozonal range. Since Ferré (1997) synonymized this microfacies taxon to a saccocomid section, we shall go further into the specific microfacies details for a better stratigraphic refinement and a true saccocomid biozonation to better serve the Mexican stratigraphy.

After a Stinnesbeck et al. (2004) illustration, we are glad to acknowledge the genuine occurrence of true roveacrinids in well-dated CenomanianTuronian Mexican deposits. Nevertheless, such $\mathrm{C} / \mathrm{T}$ sediments are not that well constrained (calcisphere microfacies, Archaeocretacea Partial Range Zone, lack of index ammonite), and roveacrinoid sections can be hard to analyze accurately. On the whole, Buitrón-Sánchez Omaña-Pulido (2015) were at least right when mentioning roveacrinidal occurrences in the CenomanianTuronian carbonate microfacies of the Valles-San Luis Potosi platform. However, the cited species are not consistent with their known stratigraphic ranges and do not fit with the illustrated sections. We can possibly assign oblique sections of indeterminate brachial plates to the family Roveacrinidae - most likely but with some extreme caution to genus Roveacrinus DOUGLAS. The presence of roveacrinidal plates (of genuine Roveacrinidae) recalls and strongly supports Aguilera-Franco's original findings $(1995,2003)$ further south in the adjacent Guerrero-Morelos Basin. This "abundance zone" of roveacrinid plates is consistent with the characteristic Roveacrinus levels mentioned around the $\mathrm{C}$ / $\mathrm{T}$ boundary in the Boreal realm and around the southern Tethysian margin (Jefferies, 1962, 1963; Gale et al., 1993; Ferré et al., 2016a, 2016b, 2017). When they are properly identified, these roveacrinoid abundance levels are potentially good indicators of the vicinity of the $\mathrm{C} / \mathrm{T}$ boundary. Moreover, when clear microfossil evidence are lacking, they can help to identify which side of the boundary (Cenomanian or Turonian) these levels belong to.

\section{Acknowledgements}

The authors wish to express their most sincere thanks to the Editor-in-Chief, Dr. Antoni Camprubí (Instituto de Geología, UNAM) for granting permission to publish, the Associate Editor, Dr Francisco Vega (Instituto de Geología, UNAM) for his assistance in the publishing process, and to the reviewers, Dr. Josep Anton Bedmar Moreno (Instituto de Geología, UNAM) and Noemí Aguilera-Franco (Soluciones Bioestratigráficas y Sedimentológicas S.C.) for their valuable effort to upgrade the spanish abstract, constructive comments and helpful advice. Phil Salvador (The Woodlands, Tx, USA) is gratefully acknowledged for the English corrections.

\section{References}

Aguilera-Franco, N., 1995, Litofacies, paleoecología y dinámica sedimentaria del Cenomaniano-Turoniano en el area de Zotoltitlan-La Esperanza, Edo. de Guerrero: Mexico City, Mexico, Universidad Nacional Autónoma de México, Facultad de Ingeniería, M.Sc. Thesis, 137 p. 
Aguilera-Franco, N., 2003, CenomanianConiacian zonation (foraminifers and calcareous algae) in the Guerrero-Morelos basin, southern Mexico: Revista Mexicana de Ciencias Geológicas, 20, 202-222.

Aguilera-Franco, N., Franco-Navarrete, S., 1995, Importancia biocronoestratigráfica e implicaciones ambientales del género Saccocoma arachnoidea (Brönniman, 1955), en el sureste de Mexico, durante el Tithoniano Medio: Boletín de la Sociedad Geológica Mexicana, 52, 21-30.

Aguilera-Franco, N., Hernández-Romano, U., 2004, Cenomanian-Turonian facies succession in the Guerrero-Morelos Basin, Southern Mexico: Sedimentary Geology, 170, 135-162.

Aguilera-Franco, N., Allison, P.A., MacLeod, N., 1997, Biostratigraphy around the Cenomanian-Turonian boundary, southern Mexico, in Bechstädt, T., Bengtson, $\mathrm{P}$. Greiling, R., Schweizer, V. (eds.), Abstracts of the 18th IAS Regional European Meeting of Sedimentology: Heidelberg, Germany, International Association of Sedimentologists, Gaea Heidelbergensis, 3, 39.

Aguilera-Franco, N., Hernández-Romano, U., Allison, P.A., 2001, Biostratigraphy and environmental changes across the Cenomanian-Turonian boundary, southern Mexico: Journal of South American Earth Sciences, 14, 237-255.

Bather, F.A., 1924, Saccocoma cretacea n. sp., a Senonian crinoid: Proceedings of the Geologists' Association, 35(2), 111-121.

Baumiller, T.K., Salamon, M.A., Gorzelak, P., Mooi, R., Messing, C.G., Gahn, F.J., 2010, Post-Paleozoic crinoid radiation in response to benthic predation preceded the Mesozoic marine revolution: Proceedings of the
National Academy of Sciences USA, 107, 5893-5896.

Bengtson, P., Berthou, P.-Y., 1983, Microfossiles et échinodermes incertae sedis des dépôts albiens à coniaciens du basin de Sergipe-Alagoas, Brésil: Cahiers de Micropaléontologie, 1982, 13-22.

Benzaggagh, M., Homberg, C., Schnyder, J., Ben Abdesselam-Mahdaoui, S., 2015, Description et biozonation des sections de crinoïdes saccocomidés du Jurassique supérieur (Oxfordien-Tithonien) du domaine téthysien occidental: Annales de Paléontologie, 101, 95-117.

Berthou, P.-Y., Bengtson, P., 1988, Stratigraphic correlation by microfacies of the Cenomanian-Coniacian of the Sergipe Basin, Brazil: Fossils and Strata, 21, 1-88.

Bonet, F., 1956, Zonificación Microfaunística de las Calizas Cretácicas del Este de México: Boletín de la Asociación Mexicana de Geólogos Petroleros, 8, 389-488.

Brönnimann, P., 1955, Microfossils incertae sedis from the Upper Jurassic and Lower Cretaceous of Cuba: Micropaleontology, 1, 28-51.

Buitrón-Sánchez, B.A., Omaña-Pulido, L., 2014, Roveacrínidos (Crinoidea, Roveacrinida) del Cenomaniano superior de la localidad de Cerritos en la Plataforma de Valles-San Luis de Potosí, México, in Hernández-Romano, U., Aranda-García, M. (eds.), Memorias de la Convención Nacional Geológica: Mexico City, Mexico, La Sociedad Geológica Mexicana A.C., 111-112.

Buitrón-Sánchez, B.E., Omaña-Pulido, L., 2015, Roveacrínidos (Crinoidea: Roveacrinida) del Cenomaniano tardío al Turoniano temprano de Cerritos, oeste de la Plataforma VallesSan Luis Potosí, México: Revista de Biología Tropical (International Journal of Tropical Biology), 63, 17-25. 
Dias-Brito, D., 1994, Comparação dos carbonatos pelágicos do Cretáceo médio da Margem Atlântica Brasileira com os do Golfo do México: Novas evidências do Tétis SulAtlantiano, in Dias-Brito, D., Ponte, F.C., Castro,J.C., Perinotto,J.A., Bertini, R.J. (eds.), Boletim do $3^{\circ}$ Simpósio sobre o Cretáceo do Brasil: Rio Claro, Brazil, Sociedade Brasileira de Geologia, 3, 11-18.

Dias-Brito, D., 1995, Calcispheras e Microfácies em Rochas Carbonáticas Pelágicas Mesocretáeas: Porto Alegre, Brazil, Universidade Federal do Rio Grande do Sul, PhD Thesis, $688 \mathrm{p}$.

Dias-Brito, D., Ferré, B., 1997, Albian Roveacrinids (stemless crinoids) in fine carbonates from the West South Atlantic, Santos Basin, Southeastern Brazil: significance, in Bechstädt, T., Bengtson, P., Greiling, R., Schweizer, V. (eds.), Abstracts of the 18th IAS Regional European Meeting of Sedimentology: Heidelberg, Germany, International Association of Sedimentologists, Gaea Heidelbergensis, 3, 118-119.

Dias-Brito, D., Ferré, B., 2001, Rovearinids [sic] (stemless crinoids) in the Albian carbonates of the offshore Santos Basin, southeastern Brazil: stratigraphic, palaeobiogeographic and palaeoceanographic significance: Journal of South American Earth Sciences, 14, 203-218.

Donofrio, D.A., Mostler, H., 1975, Neue Schwebcrinoiden aus Hallstätter Kalken des Berchtesgadener Raumes: GeologischPaläontologische Mitteilungen, 5, 1-28.

Douglas, J.A., 1908, A note on some new Chalk Crinoids: Geological Magazine, 5, 357-359.

Enos, P., Stephens, B.P., 1993, Mid-Cretaceous basin margin carbonates, east-central Mexico: Sedimentology, 40, 539-556.

Ferré, B., 1997, "Lombardia"-facies and saccocomidlike sections in Cretaceous sediments: Whose pieces?: Mineralia Slovaca, 29, 336-337.
Ferré, B., Bengtson, P., 1997, An articulated Roveacrinid from the Turonian of the Sergipe Basin, Brazil, in Bechstädt, T., Bengtson, P. Greiling, R., Schweizer, V. (eds.), Abstracts of the 18th IAS Regional European Meeting of Sedimentology: Heidelberg, Germany, International Association of Sedimentologists, Gaea Heidelbergensis, 3, 128-129.

Ferré, B., Berthou, P.-Y., 1993, Roveacrinidal remains from the Cotinguiba formation (Cenomanian-Turonian) of the Sergipe Basin (NE-Brazil), in $13^{\circ}$ Congresso Brasileiro de Paleontologia, $1^{\circ}$ Sympósio Paleontológico do Cone Sul: São Leopoldo, Brazil, Companha de Pesquisa de Recursos Minerais - Serviço Geológico do Brasil, 119.

Ferré, B., Berthou, P.-Y., 1994, Roveacrinidal remains from the Cotinguiba formation (Cenomanien-Turonien) of the Sergipe Basin (NE-Brazil): Acta Geologica Leopoldensia, XVII, 299-313.

Ferré, B., Dias-Brito, D., 1997, MicrocalamoidesMicrofacies and the Albian palaeobiogeography: Réunion spécialisée APF-SGF "De la Biostratigraphie à la Paléobiogéographie": Lyon, France, Société Géologique de France, 24.

Ferré, B., Dias-Brito, D., 1999, Microfacies recognition of Roveacrinid families Lombardia, Eothrix, Globochaete and other strains, in DiasBrito, D., de Castro, J.C., Rohn, R. (eds.), Boletim do $5^{\circ}$ Simpósio sobre o Cretáceo do Brasil: Rio Claro, Brazil, Sociedade Brasileira de Geologia, 651-659.

Ferré, B., Granier, B., 1997, The Albian stemless microcrinoids (Roveacrinidae, Crinoidea) of the Congo Basin (Angola), in Bechstädt, T., Bengtson, P., Greiling, R., Schweizer, V. (eds.), Abstracts of the 18th IAS Regional European Meeting of Sedimentology: Heidelberg, Germany, International Association of Sedimentologists, Gaea Heidelbergensis, 3, 129-130. 
Ferré, B., Granier, B., 2000, Roveacrinus berthoui nov. sp., Early Hauterivian representative of Roveacrinidae (Roveacrinida, Crinoidea) of Busot (Alicante, Spain): Geologica Carpathica, 51, 101-107.

Ferré, B., Granier, B., 2001, Albian roveacrinids from the southern Congo Basin off Angola: Journal of South American Earth Sciences, 14, 219-235.

Ferré, B., Berthou, P.-Y, Bengtson, P., 1996, Apport des Crinoïdes Rovéacrinidés à la stratigraphie du Crétacé moyen du Bassin de Sergipe (Nordeste, Brésil): Strata, 8, 101-103.

Ferré, B., Fernandez-Gonzalez, M., Dias-Brito, D., 1999, New insight into Microcalamoides Bonet, 1956-Revised systematics and subsequent bearings, in Dias-Brito, D., de Castro, J.C., Rohn, R. (eds.), Boletim do $5^{\circ}$ Simpósio sobre o Cretáceo do Brasil: Rio Claro, Brazil, Sociedade Brasileira de Geologia, 661-668.

Ferré,B.,Walter,S.,Bengtson,P., 2005, Roveacrinids in mid-Cretaceous biostratigraphy of the Sergipe Basin, northeastern Brazil: Journal of South American Earth Sciences, 19, 259-272.

Ferré, B., Benyoucef, M., Adaci, M., Zaoui, D., Piuz, A., Meister, G., Mebarki, K., Tchenar, S., Bensalah, M., 2016a, Les assemblages microfaciologiques de Rovéacrinidés (Crinoïdes) de la région de Tinrhert (S.E.Algérie) à la limite cénomano-turonienne - Roveacrinid microfacies assemblages (Crinoidea) from the Tinrhert area (SEAlgeria) at the Cenomanian-Turonian boundary, in Morel, N., Desmares, D., Néraudeau, D. (eds.), Volume des résumés, Colloque Cénomanien: Le Mans, France, Groupe Français du Crétacé, 32-35.

Ferré, B., Benyoucef, M., Zaoui, D., Adaci, M., Piuz, A., Tchenar, S., Meister, C., Mebarki,
K., Bensalah, M., 2016b, CenomanianTuronian roveacrinid microfacies assemblages (Crinoidea, Roveacrinida) from the Tinrhert area (SE Algeria) - Assemblages microfaciologiques de rovéacrinides (Crinoidea, Roveacrinida) du CénomanoTuronien de la région de Tinrhert (Algérie du Sud-Est): Annales de Paléontologie, 102, 225-235.

Ferré, B., Mebarki, K., Benyoucef, M., Villier, L., Bulot, L. G., Desmares, D., BoumedièneBenachour, H., Marie, L., Sauvagnat, J., Bensalah, M., Zaoui, D., Adaci, M., 2017, Roveacrinids (Crinoidea, Roveacrinida) from the Cenomanian-Turonian of southwest Algeria (Saharan Atlas and Guir Basin) - Ossicules de rovéacrinides (Crinoidea, Roveacrinida) cénomano-turoniens du sudouest algérien (Atlas saharien et Bassin du Guir): Annales de Paléontologie, 103, 185-196.

Gale, A.S., 2016, Roveacrinida (Crinoidea, Articulata) from the Santonian-Maastrichtian (Upper Cretaceous) of England, the US Gulf Coast (Texas, Mississippi) and southern Sweden: Papers in Palaeontology, 2, 489-532.

Gale, A.S., 2017, An integrated microcrinoid zonation for the lower Campanian chalks of southern England, and its implications for correlation: Cretaceous Research, 87, 312-357.

Gale, A.S., Jenkyns, H.C., Kennedy, W.J., Corfield, R.M., 1993, Chemostratigraphy versus biostratigraphy: Data from around the Cenomanian-Turonian boundary: Journal of the Geological Society, 150, 29-32.

Geinitz, H.B., 1871, Das Elbthalgebirge in Sachsen. Erster Theil. Der untere Quader: Palaeontographica, 20(1), I.1-I.319. 
Goldfuss, G.A., 1826-1844, Petrefacta Germaniæ tam ea quae in Museo Universitatis Regiae Borussicae Fridericiae Wilhelmiae Rhenanae servantur quam alia quaecunque in Museis Hoeninghusiano Muensteriano aliisque extant, iconibus et descriptionibus illustrata - Abbildungen und Beschreibungen der Petrefacten Deutschlands und der angränzenden Länder, unter Mitwerkung des Herrn Grafen Georg zu Münster, herausgegeben von August Goldfuss: Düsseldorf, Germany, Arnz Co. 234 p. (1 vol.), 298 p. ( $2^{\circ}$ vol.), 120 p. ( $3^{\circ}$ vol. $), 200$ pls. (4 $4^{\circ} \mathrm{vol}$.).

Gorzelak, P., Salamon, M.A., Ferré, B., 2011, Pelagic crinoids (Roveacrinida, Crinoidea) discovered in the Neogene of Poland: Naturwissenschaften, 98, 903-908.

Gorzelak, P., Salamon, M.A., Baumiller, T.K., 2012, Predator-induced macroevolutionary trends in Mesozoic crinoids: Proceedings of the National Academy of Sciences USA, 109, 7004-7007.

Gorzelak, P., Salamon, M.A., Trzęsiok, D., Lach, R., Baumiller, T. K., 2016, Diversity dynamics of post-Palaeozoic crinoids - in quest of the factors affecting crinoid macroevolution: Lethaia, 49, 231-244.

Gréselle, B., Callot, P., Grélaud, C., Razin, P., Embry, J.C., Hunt, D.W., 2009, Transition plate-forme bassin dans l'Albien du Coahuila Block (Albien, NE du Mexique). Contraintes faciologiques et géométriques, in Livre des résumés 12ème Congrès Français de Sédimentologie: Rennes, France, Association des Sédimentologistes Français, 87.

Gréselle, B., Gallot, P., Grélaud, C., Razin, P., Embry, J.C., Hunt, D.W., 2010, Stratigraphic architecture and facies distribution within the Early Aptian - Early Cenomanian carbonate platform of the Coahuila Block (NE Mexico), in Strati2010, 4ème Congrès Français de
Stratigraphie: Paris, France, Comité Français de Stratigraphie, 116.

Hernández-Romano, U., Aguilera-Franco, N., Martínez-Medrano, M., Barceló-Duarte, J., 1997, Guerrero-Morelos Platform drowning at the Cenomanian-Turonian boundary, Huitziltepec area, Guerrero State, southern Mexico: Cretaceous Research, 18, 661-686.

Hess, H., 2002, Remains of Saccocomids (Crinoidea: Echinodermata) from the Upper Jurassic of southern Germany: Stuttgarter Beiträge zur Naturkunde, Serie B (Geologie und Paläontologie), 329, 1-57.

Hess, H., 2015, Roveacrinids (Crinoidea) from the mid-Cretaceous of Texas: ontogeny, phylogeny, functional morphology and lifestyle: Swiss Journal of Palaeontology, 134, 77-107.

Hess, H., Messing, G.G., 2011, Treatise on Invertebrate Paleontology, Part T (Revised), Echinodermata 2, Crinoidea: Lawrence, Kansas, USA, The University of Kansas and The Geological Society of America, 261 p.

Hess, H., Etter, W., Hagdorn, H., 2016, Roveacrinida (Crinoidea) from Late Triassic (early Carnian) black shales of Southwest China: Swiss Journal of Palaeontology, 135, 249-274.

Jagt, J.M.W., 1999, Late Cretaceous-Early Palaeogene echinoderms and the $\mathrm{K} / \mathrm{T}$ boundary in the southeast Netherlands and northeast Belgium - Part 1: Introduction and stratigraphy, Part 2: Crinoids: Scripta Geologica, 116, 1-255.

Jefferies, R.P.S., 1962, The palaeoecology of the Actinocamax plenus Subzone (Lowest Turonian) in the Anglo-Paris Basin: Palaeontology, 4, 609-674.

Jefferies, R.P.S., 1963, The stratigraphy of the Actinocamax plenus Subzone (Lowest Turonian) in the Anglo-Paris Basin: Proceedings of the Geologists' Association, 74, 1-33. 
Kozur, H., Mostler, H., 1971, HolothurienSklerite und Conodonten aus der Mittel- und Obertrias von Köveskal (Balatonhochland, Ungarn): Geologisch-Paläontologische Mitteilungen, 1, 1-36.

Kristan-Tollmann, E., 1975,Die Osteokrinusfazies, ein Leithorizont von Schwebcrinoiden im Oberladin-Unterkarn der Tethys: Erdöl und Kohle, Erdgas, Petrochemie vereinigt mit Brennstoff-Chemie, 23, 781-789.

Kristan-Tollmann, E., 1977, Zur Gattungsunterscheidung und Rekonstruktion der triadischen Schwebcrinoiden: Paläontologische Zeitschrift, 51, 185-198.

Kristan-Tollmann, E., 1991, Echinoderms from the Middle Triassic Sina Formation (Aghdarband Group) in NE Iran: Abhandlungen Geologischen Bundesanstalt, 38, 175-194.

Kristan-Tollmann, E., Krystyn, L., 1975, Die Mikrofauna der ladinisch-karnischen Hallstätter Kalke von Saklibeli (TaurusGebirge, Türkei): Sitzungsberichte der Österreichiche Akademie der Wissenschaften, Mathematisch-naturwissenschaftliche Klasse, 184, 259-340.

Kristan-Tollmann, E., Tollmann, A., 1981, Die Stellung der Tethys in der Trias und die Herkunft ihrer Fauna: Mitteilungen der Österreichischen Geologischen Gesellschaft, 74-75, 129-135.

Lombard, A., 1937, Microfossiles d'attribution incertaine du Jurassique supérieur alpin: Eclogae Geologicae Helvetiae, 30, 320-331.

Lombard, A., 1945, Attribution de microfossiles du Jurassique supérieur alpin à des Chlorophycées (Proto- et Pleurococcacées): Eclogae Geologicae Helvetiae, 38, 163-173.

Longoria,J.F., Monreal,R., 1991,Lithostratigraphy, microfacies, and depositional environments of the Mesozoic of Sierra La Nieve, Coahuila, northeast Mexico: Revista de la Sociedad Geológica de España, 4, 7-31.
López-Martínez, R.A., Barragán-Manzo, R., Buitrón-Sánchez, B.E.M., Rojas-Consuela, R., 2014, Sea level changes through the Jurassic/Cretaceous boundary in western Cuba indicated by taphonomic analysis: Boletín de la Sociedad Geológica Mexicana, 66, 431-440.

McNulty, G.L., 1985, Micropaleontological stratigraphic framework for the Cretaceous black lime wackestone-mudstone facies of the Gulf of Mexico, in Perkins, B.F., Martin G.B. (eds.), Habitat of Oil and Gas in the Gulf Coast, Proceedings of the Fourth Annual research Conference Gulf Coast Section: Tulsa, Oklahoma, U.S.A., Society of Economic Paleontologists and Mineralogists, Society for Sedimentary Geology, 1176-1191.

Milsom, G.V., 1989, In search of truly pelagic crinoids, in Abstracts of the Annual Conference of the Palaeontological Association: Liverpool, UK, The Palaeontological Association, 13.

Monier-Castillo, A., Ferré, B., López-Palomino, I., Aguilera-Franco, N., Palma-Ramírez, A., Contreras-Cruz, D., Reyes-Ramírez, J.R., Muñoz-Jarillo, G.R., 2017a, Asociación de Roveacrínidos del Albiano de Sierra Azul, Cuenca de Sabinas, Coahuila, México, in Libro de Resúmenes XV Congreso Nacional de Paleontología: San Luis Potosí, Mexico, Sociedad Mexicana de Paleontología, A.C., 97.

Monier-Castillo, A., Ferré, B., López-Palomino, I., Aguilera-Franco, N., Palma-Ramírez, A., Contreras-Cruz, D., Reyes-Ramírez, J.R., Muñoz-Jarillo, C.R., 2017b, Asociación de Roveacrínidos del Albiano de Sierra Azul, Cuenca de Sabinas, Coahuila, México, in XV Congreso Nacional de Paleontología, SOMEXPAL: San Luis Potosí, Mexico, Sociedad Mexicana de Paleontología, A.C., Poster, doi:10.13140/RG.2.2.11231.87201. 
Mostler, H., 1972, Die stratigraphische Bedeutung von Crinoiden-, Echinidenund Ophiuren-Skelettelementen in triassischen Karbonatgesteinen: Mitteilungen der Gesellschaft für Geologie und Bergbaustudenten in Österreich, 21, 711-728.

Niebuhr, B., Ferré, B., 2016, 12. Crinoiden (Seelilien), in Niebuhr, B., Wilmsen, M. (eds.), Kreide-Fossilien in Sachsen, Teil 2: Geologica saxonica (Journal of Central European Geology), 62, 103-112.

Núñez-Useche, F., Barragán, R., 2012, Microfacies analysis and paleoenvironmental dynamic of the Barremian-Albian interval in Sierra del Rosario, eastern Durango state, Mexico: Revista Mexicana de Ciencias Geológicas, 29, 204-218.

Omaña, L., Torres, J.R., López-Doncel, R., Alencáster, G., López-Caballero, I., 2014, A pithonellid bloom in the CenomanianTuronian boundary interval from Cerritos in the western Valles-San Luis Potosi platform, Mexico: Paleoenvironmental significance: Revista Mexicana de Ciencias Geológicas, 31, 28-44.

O’Neill, P., Waite, R., 1969, The Upper Jurassic and Cretaceous Nannofossils succession at Peregrina Canyon, Tamaulipas, México: Houston, Texas, Shell Oil Co. Serial Memo. IR. O. Exploration 74-3, 150 p.

Peck, R.E., 1943, Lower Cretaceous crinoids from Texas: Journal of Paleontology, 17, 451-475.

Peck, R.E., 1948, A Triassic crinoid from Mexico: Journal of Paleontology, 22, 81-84.

Peck, R.E., 1955, Cretaceous Microcrinoids from England: Journal of Paleontology, 29(6), 1019-1029.

Peck, R.E., 1973, Applinocrinus, a New Genus of Cretaceous Microcrinoids and Its Distribution in North America: Journal of Paleontology, 47, 94-100.
Rasmussen, H.W., 1961, A Monograph on the Cretaceous Crinoidea: Biologiske Skrifter udgivet af Det Kongelige Danske Videnskabernes Selskab, 12, 1-428.

Rosales-Dominguez, M. del C., GrajalesNishimura, J.M., Sánchez-Ríos, M.A., Gómez-Luna, M.A., Dueñas, M.A., 1995, Biostratigraphy of the Lower Cretaceous Bisbee Group, Rancho Culantrillo area, northeastern Sonora, in Jacques-Ayala, C., González-Léon, G.M., Roldán-Quintana, J. (eds.), Studies on the Mesozoic of Sonora and Adjacent Areas: Geological Society of America Special Papers, 301, 49-57.

Salamon, M.A., Gorzelak, P., Ferré, B., Lach, R., 2010, Roveacrinids (Crinoidea, Echinodermata) survived the CretaceousPaleogene (K-Pg) extinction event: Geology, 38, 883-885.

Salamon, M.A., Gorzelak, P., Hanken, N.-M., Riise, H.E., Ferré, B., 2015, Crinoids from Svalbard in the aftermath of the end-Permian mass extinction: Polish Polar Research, 36, 225-238.

Schlanger, S.O., Jenkyns, H.C., 1976, Cretaceous oceanic anoxic events: causes and consequences: Geologie en Mijnbouw (Netherlands Journal of Geosciences), 55, 179-184.

Schneider, H.L., 1987, Zur Kelchmorphologie und Systematik der Roveacrininae PECK, 1943 (Crinoidea, Oberkreide): Neues Jahrbuch für Geologie und Paläontologie Abhandlungen, 175, 181-206.

Schneider, H.L., 1989, Zur Morphologie und Ontogenese von Roveacrimus geinitzi n. sp. (Crinoidea, Oberkreide): Neues Jahrbuch für Geologie und Paläontologie Abhandlungen, 178, 167-181.

Scott, R.W., Root, S.A., Tenery, J.H., Nestell, M., 1977, Morphology of the cretaceous microcrinoid Poecilocrinus (Roveacrinidae): Journal of Paleontology, 51, 343-349. 
Scott, R.W., Campbell, W., Hojnacki, R., Wang, Y., Lai, X., 2016, Albian rudist biostratigraphy (Bivalvia), Comanche shelf to shelf margin, Texas: Carnets de Géologie, 16, 513-541.

Souza-Lima, W., de Castro Manso, C.L., 2000, Os fosséis da bacia de Sergipe-Alagoas, Os crinóides e asteróides: Phoenix, 22, 1-2.

Stinnesbeck, W., Keller, G., Adatte, T., Harting, M., Stüben, D., Istrate, G., Kramar, U., 2004, Yaxcopoil-1 and the Chicxulub impact: International Journal of Earth Sciences (Geologische Rundschau), 93, 1042-1065.

Trejo, H.M., 1975, Zonificación del límite Aptiano-Albiano de México: Revista del Instituto Mexicano del Petróleo, 7, 6-29.

Trejo, H.M., 1981, Bioestratigrafia de la serie Coahuila en sus facies de plataforma, area de Monclova, Coahuila: Revista del Instituto Mexicano del Petróleo, 13, 5-23.

Trejo, H.M., 1983, Paleobiología y taxonomía de algunos fósiles mesozoicos de México: Boletín de la Sociedad Geológica Mexicana, 44, 1-82.

Trejo, H.M., Bautista, L., 1977, Estudio Bioestratigráfico del Cretácico Inferior y
Jurásico Superior del Noreste de México: Mexico, Instituto Mexicano del Petróleo, Proyecto C-3021.

Verniory, R., 1954, Eothrix alpina Lombard, Algue ou Crinoïde?: Archives des Sciences Genève, 7, 327-330.

Verniory, R., 1955, Extension géographique et stratigraphique du genre Saccocoma Agassiz dans le Dauphiné méridional et en Provence: Archives des Sciences Genève, 8, 225-226.

Verniory, R., 1956, La création du genre Lombardia Brönnimann est-elle justifiée?: Archives des Sciences Genève, 9, 86-92.

Verniory, R., 1960, Présence (et variétés) de Saccocoma tenella Goldfuss à Talloires (HauteSavoie): Archives des Sciences Genève, 13, 250-257.

Verniory, R., 1961, Présence de Saccocoma quenstedti Doreck (in coll.) dans les gorges de la Méouge (Sisteron Provence): Archives des Sciences Genève, 14, 315-320.

Verniory, R., 1962, Une nouvelle forme de Saccocoma (Montbrand, Hautes-Alpes, France): Archives des Sciences Genève, 15, 391-397. 


\section{Appendix A}

Revised taxonomical list of roveacrinid taxa (found in the literature) occurring in Mexico and adjacent areas (Cuba, U.S. Gulf Coast).

\section{Axicrinidae [unreported]}

\section{Somphocrinidae}

Somphocrinus [OD: Peck, 1948]

Somphocrinus mexicanus Peck, 1948 [OD: Peck, 1948;

synonymy lists]

\section{Saccocomidae}

Applinocrinus [= Microcalamoides Bonet, 1956]

Applinocrinus cretaceus (Bather, 1924) [Peck, 1973:

Campanian from the US Gulf Coast and Jamaica, and the Mendez Shale of? Tamaulipas or? Nuevo Leon, Mexico]

Applinocrinus texanus Peck, 1973 [OD, Peck, 1973; Uppermost Campanian-lower Maastrichtian of Texas, Florida and Mississippi: Gale, 2016] Applinocrinus sp. [= Microcalamoides diversus Bonet, 1956; M. confusus Trejo, 1983; M. ornatus Trejo, 1983: for review, see Ferré et al., 1999]

"Microcalamoides" spp. [junior synonyms of Applinocrinus spp., non-conservative specific assignment]

"Saccocoma" [= Lombardia Brönnimann, 1955; to date, any Cretaceous Saccocoma reference should be regarded as a saccocomid better to as potential genuine Applinocrinus; along with some slanted references of Globochaete alpina Lombard (support) and Eothrix alpina Lombard]

Saccocomidae indet. [López-Martínez et al., 2014)]

\section{Roveacrinidae}

Discocrinus [OD: Peck, 1943]

Discocrinus catastomus Peck, 1943 [Duck Creek and lower Fort Worth Fms, Texas]

Orthogonocrinus apertus Peck, 1943 [Duck Creek and Grayson Fms, Texas]

Poecilocrinus [OD: Peck, 1943]

Poecilocrinus dispandus Peck, 1943 [Fort Worth to Main Street Fms, Texas and Oklahoma; Peck,
1943; Scott et al., 1977; non Buitrón-Sánchez and Omaña-Pulido, 2015]

P. dispandus elongatus Peck, 1943 [Peck, 1943: Weno Fm., Texas; non Buitrón-Sánchez and OmañaPulido, 2014, 2015]

P. dispandus explicatus Peck, 1943 [Main Street Fm., Texas]

P. dispandus molestus Peck, 1943 [Main Street Fm., Texas]

P. latealatus (Peck, 1943) [= Roveacrinus latealatus PECK from the Fort Worth Fm. of Texas; Hess, 2015]

P. pendulus Peck, 1943 [Duck Creek and lower Fort Worth Fms., Texas]

P. porcatus Peck, 1943 [Duck Creek and lower Fort Worth Fms., Texas]

P. spiculatus Peck, 1943 [Duck Creek and lower Fort Worth Fms., Texas]

Plotocrinus [OD: Peck, 1943]

Plotocrinus distinctus Peck, 1943 [Goodland and Kiamichi Fms., Texas]

P. hemisphericus Peck, 1943 [Duck Creek and lower Fort Worth Fms., Texas; non Pl. 71 fig. 4 in Peck, 1943: 456 - Roveacrinus latealatus (Peck); Hess, 2015: 80]

P. inornatus Peck, 1943 [Duck Creek and lower Fort Worth Fms., Texas]

P. modulatus Peck, 1943 [Duck Creek Fm., Texas]

P. primitivus Peck, 1943 [= Roveacrinus pyramidalis PECK ? from the Goodland and Kiamichi Fms., Texas: Hess, 2015]

Roveacrinus alatus Douglas, 1908 [= Roveacrinus pentagonus PECK from the Grayson Fm. of Texas: HESS, 2015; "Planktic crinoid": Aguilera-Franco and Hernández-Romano, 2004; Stinnesbeck et al., 2004]

R. euglypheus Peck, 1943 [Grayson Fm., Texas]

R. geinitzi Schneider, 1989 [Aguilera-Franco et al., 2001; Aguilera-Franco, 2003; non Buitrón-Sánchez and Omaña-Pulido, 2014, 2015] 
R. cf. geinitzi Schneider, 1989 [Aguilera-Franco and Hernández-Romano, 2004]

R. multisinuatus Peck, 1943 [Main Street and Grayson Fms., Texas]

R. peracutus (Peck, 1943) [Goodland to Grayson Fms., Texas; ex Drepanocrinus: Hess, 2015]

R. pyramidalis Peck, 1943 [Duck Creek to Grayson Fms., Texas; = Plotocrinus primitivus Peck, 1943? from the Goodland and Kiamichi Fms., Texas: Hess, 2015]

Roveacrinus aff. rugosus Douglas, 1908 [AguileraFranco, 2003]

R. signatus PECK, 1943 [Main Street and Grayson Fms., Texas]
R. spinalatus Peck, 1943 [Grayson Fm., Texas] R. spinosus Peck, 1943 [Main Street and Grayson Fms., Texas]

Roveacrinus sp. cf. alatus Douglas, 1908 [AguileraFranco et al., 2001]

Roveacrinus sp. [Aguilera Franco et al., 2001; Aguilera-Franco and Hernández-Romano, 2004; "R. geinitzi Schneider", non Roveacrinus sp.: BuitrónSánchez and Omaña-Pulido, 2014; Omaña et al., 2014]

Roveacrinidae indet. [Núñez-Useche and Barragán, 2012; "R. geinitzi Schneider", non Roveacrinus sp.: Omaña et al., 2014; López-Martínez et al., 2014; Buitron-Sánchez and Omaña-Pulido, 2015. 


\section{Appendix B}

Table 1. Correspondance between published roveacrinid taxa and their revised assignment.

\begin{tabular}{|c|c|c|c|c|c|}
\hline Authors (Date) & Illustrations & Original identification & Age & Revised Identification & Revisited Age \\
\hline \multirow{30}{*}{ Peck (1943) } & p. 461 & $\begin{array}{l}\text { Family Roveacrinidae } \\
\text { n. fam. [OD] }\end{array}$ & $\begin{array}{c}\text { Cretaceous } \\
\text { North America }\end{array}$ & & \\
\hline & p. 462 & $\begin{array}{c}\text { Subfamily Drepanocrininae } \\
\text { n. subfam. [OD] }\end{array}$ & Lower Cretaceous of Texas & & \\
\hline & $\begin{array}{c}\text { p. } 463 \\
\text { Pl. } 76 \text { Figs. } 9-22,26,28\end{array}$ & $\begin{array}{c}\text { Drepanocrinus peracutus Peck, } \\
\text { n. sp. }\end{array}$ & $\begin{array}{l}\text { Lower Cretaceous of Texas } \\
\text { Goodland to Grayson Fms. }\end{array}$ & $\begin{array}{c}\text { Roveacrinus peracutus (Peck, } \\
\text { 1943) } \\
{[\text { Hess, 2015] }}\end{array}$ & \\
\hline & p. 464 & Orthogonocrinus Peck, n. sp. & $\begin{array}{c}\text { Lower Cretaceous } \\
\text { of Texas }\end{array}$ & & \\
\hline & $\begin{array}{c}\text { p. } 464 \\
\text { Pl. } 76 \text { figs. } 2-8\end{array}$ & $\begin{array}{l}\text { Orthogonocrinus apertus Peck, } \\
\text { n. sp. }\end{array}$ & Duck Creek to Grayson Fms. & & \\
\hline & p. 465 & $\begin{array}{c}\text { Subfamily Roveacrininae } \\
\text { n. subfam. }\end{array}$ & Lower Cretaceous of Texas & & \\
\hline & $\begin{array}{c}\text { p. } 466 \\
\text { Pl. } 74 \text { figs. } 1-5,11-14\end{array}$ & $\begin{array}{l}\text { Roveacrinus signatus Peck, } \\
\text { n. sp. }\end{array}$ & Main Street and Grayson Fms. & & \\
\hline & $\begin{array}{c}\text { p. } 466 \\
\text { Pl. } 72 \text { figs. } 8,14-17\end{array}$ & $\begin{array}{c}\text { Roveacrinus multisinuatus } \text { Peck, } \\
\text { n. sp. }\end{array}$ & Grayson Fm. & & \\
\hline & $\begin{array}{l}\text { p. } 467 \\
\text { Pl. } 72 \text { figs. } 12 ; \\
\text { Pl. } 73 \text { figs } 1-7,7\end{array}$ & $\begin{array}{l}\text { Roveacrinus pentagonus Peck, } \\
\text { n. sp. }\end{array}$ & Grayson Fm. & $\begin{array}{c}\text { Roveacrinus alatus Douglas } \\
\text { [Hess, 2015] }\end{array}$ & \\
\hline & $\begin{array}{l}\text { p. } 467 \\
\text { Pl. } 74 \text { figs. } 6-7,9 ; \text { Pl. } 76 \\
\text { figs. } 37,39\end{array}$ & $\begin{array}{l}\text { Roveacrinus spinosus Peck, } \\
\text { n. sp. }\end{array}$ & Grayson and Main Street Fms. & & \\
\hline & $\begin{array}{c}\text { p. } 467 \\
\text { Pl. } 74 \text { figs. } 8,10\end{array}$ & $\begin{array}{c}\text { Roveacrinus spinalatus } \text { Peck, } \\
\text { n. sp. }\end{array}$ & Grayson Fm. & & \\
\hline & $\begin{array}{l}\text { p. } 468 \\
\text { Pl. } 73 \text { figs. } 9-12,14 ; \text { Pl. } 76 \\
\text { fig. } 1\end{array}$ & $\begin{array}{l}\text { Roveacrinus latealatus } \text { Peck, } \\
\text { n. sp. }\end{array}$ & Fort Worth Fm. & $\begin{array}{l}\text { Poecilocrinus latealatus } \\
\text { (Peck) } \\
{[\text { Hess, 2015] }}\end{array}$ & \\
\hline & $\begin{array}{c}\text { p. } 468 \\
\text { Pl. } 72 \text { figs. } 24-29\end{array}$ & $\begin{array}{c}\text { Roveacrinus pyramidalis Peck, } \\
\text { n. sp. }\end{array}$ & Duck Creek to Grayson Fms. & & \\
\hline & $\begin{array}{c}\text { p. } 469 \\
\text { Pl. } 72 \text { figs. } 18-23\end{array}$ & $\begin{array}{c}\text { Roveacrimus euglypheus Peck, } \\
\text { n. sp. }\end{array}$ & Grayson Fm. & & \\
\hline & P. 469 & Plotocrinus Peck, n. gen. & $\begin{array}{l}\text { Lower Cretaceous } \\
\text { of Texas }\end{array}$ & & \\
\hline & $\begin{array}{c}\text { p. } 469 \\
\text { Pl. } 71 \text { figs. } 4-5,7-15,24\end{array}$ & $\begin{array}{c}\text { Plotocrinus hemisphericus } \text { Peck, } \\
\text { n. sp. }\end{array}$ & $\begin{array}{l}\text { Duck Creek and lower Fort } \\
\text { Worth Fms. }\end{array}$ & $\begin{array}{c}\text { Pl. } 71 \text { fig. 4: Roveacrinus } \\
\text { latealatus } \text { (Peck) } \\
\text { [Hess, 2015] }\end{array}$ & \\
\hline & $\begin{array}{c}\text { p. } 470 \\
\text { Pl. } 71 \text { figs. } 16-18,23\end{array}$ & $\begin{array}{l}\text { Plotocrinus modulatus Peck, } \\
\text { n. sp. }\end{array}$ & Duck Creek Fm. & & \\
\hline & $\begin{array}{c}\text { p. } 470 \\
\text { Pl. } 71 \text { figs. } 6,19-22\end{array}$ & $\begin{array}{c}\text { Plotocrinus inornatus Peck, } \\
\text { n. sp. }\end{array}$ & $\begin{array}{l}\text { Duck Creek and lower Fort } \\
\text { Worth Fms. }\end{array}$ & & \\
\hline & $\begin{array}{c}\text { p. } 470 \\
\text { Pl. } 71 \text { figs. } 1-3\end{array}$ & $\begin{array}{l}\text { Plotocrinus primitivus Peck, } \\
\text { n. sp. }\end{array}$ & Goodland and Kiamichi Fms. & $\begin{array}{c}\text { Roveacrinus pyramidalis } \text { Peck } \\
? \\
{[\text { Hess, 2015] }}\end{array}$ & \\
\hline & $\begin{array}{c}\text { p. } 471 \\
\text { Pl. } 72 \text { figs. } 1,7,13\end{array}$ & $\begin{array}{l}\text { Plotocrinus distinctus Peck, } \\
\text { n. sp. }\end{array}$ & Goodland and Kiamichi Fms. & & \\
\hline & p. 471 & Poecilocrinus Peck, n. gen. & $\begin{array}{l}\text { Lower Cretaceous } \\
\text { of Texas }\end{array}$ & & \\
\hline & $\begin{array}{c}\text { p. } 471 \\
\text { Pl. } 75 \text {, figs. } 1-2,6,8,12\end{array}$ & $\begin{array}{c}\text { Poecilocrinus dispandus Peck, } \\
\text { n. sp. }\end{array}$ & $\begin{array}{c}\text { Fort Worth to Main Street } \\
\text { Fms. }\end{array}$ & & \\
\hline & $\begin{array}{c}\text { p. } 471 \\
\text { P1. } 75 \text { fig. } 7\end{array}$ & $\begin{array}{c}\text { Poecilocrinus dispandus } \\
\text { elongatus } \text { Peck, n. var. }\end{array}$ & Weno Fm. & & \\
\hline & $\begin{array}{c}\text { p. } 472 \\
\text { Pl. } 75 \text { figs. } 11,14\end{array}$ & $\begin{array}{l}\text { Poecilocrinus dispandus } \\
\text { explicatus } \text { Peck, } \mathrm{n} \text {. var. }\end{array}$ & Main Street Fm. & & \\
\hline & $\begin{array}{c}\text { p. } 472 \\
\text { Pl. } 75 \text { fig. } 4\end{array}$ & $\begin{array}{l}\text { Poecilocrinus dispandus } \\
\text { molestus Peck, n. var. }\end{array}$ & Main Street Fm. & & \\
\hline & $\begin{array}{c}\text { p. } 472 \\
\text { Pl. } 73 \text { figs. } 6,8,13\end{array}$ & $\begin{array}{c}\text { Poecilocrinus spiculatus Peck, } \\
\text { n. sp. }\end{array}$ & $\begin{array}{l}\text { Duck Creek and lower Fort } \\
\text { Worth Fms. }\end{array}$ & & \\
\hline & $\begin{array}{c}\text { p. } 474 \\
\text { P1. } 75 \text { figs. } 3,5,9-10,13\end{array}$ & $\begin{array}{l}\text { Poecilocrinus pendulus } \text { Peck, } \\
\text { n. sp. }\end{array}$ & $\begin{array}{c}\text { Duck Creek and lower Fort } \\
\text { Worth Fms. }\end{array}$ & & \\
\hline & $\begin{array}{c}\text { p. } 474 \\
\text { Pl. } 72 \text { figs. } 2-6\end{array}$ & $\begin{array}{l}\text { Poecilocrinus porcatus Peck, } \\
\text { n. sp. }\end{array}$ & $\begin{array}{c}\text { Duck Creek and lower Fort } \\
\text { Worth Fms. }\end{array}$ & & \\
\hline & p. 474 & Discocrinus Peck, n. gen. & $\begin{array}{c}\text { Lower Cretaceous } \\
\text { of Texas }\end{array}$ & & \\
\hline & $\begin{array}{c}\text { p. } 474 \\
\text { Pl. } 72 \text { figs. } 9-11\end{array}$ & $\begin{array}{c}\text { Discocrinus catastomus } \text { Peck, } \\
\text { n. sp. }\end{array}$ & $\begin{array}{c}\text { Duck Creek and lower Fort } \\
\text { Worth Fms. }\end{array}$ & & \\
\hline
\end{tabular}


Table 1. Correspondance between published roveacrinid taxa and their revised assignment (continuation).

\begin{tabular}{|c|c|c|c|c|c|}
\hline Authors (Date) & Illustrations & Original identification & Age & Revised Identification & Revisited Age \\
\hline \multirow[b]{2}{*}{ Peck (1948) } & p. 82 & Somphocrinus n. gen. & & & \\
\hline & $\begin{array}{c}\text { p. } 82 \\
\text { Pl. } 20 \text { Figs. } 1-38\end{array}$ & $\begin{array}{l}\text { Somphocrinus mexicanus n. sp. } \\
{[\mathrm{OD}]}\end{array}$ & $\begin{array}{l}\text { Lower part (Carnian) of Upper } \\
\text { Triassic } \\
\text { Cerro Colorado (or Cerro de la } \\
\text { Cruz), Sonora, Mx }\end{array}$ & & \\
\hline \multirow{7}{*}{ Brönnimann (1955) } & $\begin{array}{c}\text { p. } 42 \\
\text { Text-figs. 6a-k, o-s }\end{array}$ & Globochaete alpina Lombard & $\begin{array}{c}\text { Middle Portlandian } \\
\text { Las Villas Province, } \\
\text { Cuba }\end{array}$ & $\begin{array}{l}\text { Text-fig. 6o: (?) Transverse } \\
\text { section of a radial plate } \\
\text { (TS-rad) } \\
\text { "Saccocoma" sp. }\end{array}$ & \\
\hline & Text-fig. $t$ & Group of aptychi & $\begin{array}{l}\text { Middle Portlandian } \\
\text { Las Villas Province, } \\
\text { Cuba }\end{array}$ & $\begin{array}{c}\text { [lower section]: (?) Transverse } \\
\text { section of a radial plate } \\
\text { (TS-rad) } \\
\text { "Saccocoma" sp. }\end{array}$ & \\
\hline & $\begin{array}{c}\text { p. } 43 \\
\text { Text-figs. 6n-1 }\end{array}$ & Eothrix alpina Lombard? & $\begin{array}{l}\text { Middle Portlandian } \\
\text { Las Villas Province, } \\
\text { Cuba }\end{array}$ & $\begin{array}{l}\text { (?) Transverse section of a } \\
\text { radial plate } \\
\text { (TS-rad) } \\
\text { "Saccocoma" sp. }\end{array}$ & \\
\hline & p. $43-44$ & Lombardia $\mathrm{n}$. gen. & & & \\
\hline & $\begin{array}{l}\text { p. } 44 \\
\text { Pl. } 1 \text { figs. } 18-20,24(?), \\
\text { Text-figs. } 7-8\end{array}$ & $\begin{array}{l}\text { Lombardia arachnoidea } \\
\text { n. sp. }\end{array}$ & $\begin{array}{l}\text { Middle Portlandian } \\
\text { Las Villas Province, } \\
\text { Cuba }\end{array}$ & $\begin{array}{c}\text { Transverse sections of brachial } \\
\text { plates } \\
\text { (TS-NBrn) } \\
\text { "Saccocoma" sp. }\end{array}$ & \\
\hline & $\begin{array}{l}\text { p. } 44 \\
\text { Pl. } 1 \text { fig. } 22 \text {, } \\
\text { Text-fig. } 9\end{array}$ & $\begin{array}{l}\text { Lombardia perplexa } \\
\text { n. sp. }\end{array}$ & $\begin{array}{l}\text { Middle Portlandian } \\
\text { Las Villas Province, } \\
\text { Cuba }\end{array}$ & $\begin{array}{c}\text { Oblique sections of brachial } \\
\text { plates } \\
\text { (OblS-NBrn) } \\
\text { "Saccocoma"sp. }\end{array}$ & \\
\hline & $\begin{array}{l}\text { p. } 44 \\
\text { Pl. } 1 \text { fig. } 23 \text {, } \\
\text { Text-fig. } 10\end{array}$ & $\begin{array}{l}\text { Lombardia angulata } \\
\text { n. sp. }\end{array}$ & $\begin{array}{l}\text { Middle Portlandian } \\
\text { Las Villas Province, } \\
\text { Cuba }\end{array}$ & $\begin{array}{c}\text { Longitudinal (Transverse) } \\
\text { sections of brachial plates } \\
\text { (LgS-Nbrn) } \\
\text { "Saccocoma" sp. }\end{array}$ & \\
\hline \multirow{4}{*}{ Bonet (1956) } & p. 47 & $\begin{array}{c}\text { Microcalamoides gen. nov. } \\
{[\text { [OD] }}\end{array}$ & Barremian-lower Albian & Applinocrinus Peck, 1973 & $\begin{array}{l}\text { Barremian(?)-Aptian- } \\
\text { Albian }\end{array}$ \\
\hline & $\begin{array}{l}\text { p. } 47 \text { Pls. } \\
\text { XXVII [sic], [XXVIII] } \\
\text { XXIX-XXX }\end{array}$ & $\begin{array}{l}\text { Microcalamoides diversus nov. } \\
\text { sp. }\end{array}$ & $\begin{array}{c}\text { Cañon de Lajitas } \\
\text { Sierra de Tamaulipas } \\
\text { La Peña, Cupido, Lower } \\
\text { Tamaulipas and Ahuacatlán } \\
\text { Fms. } \\
\text { basal Barremian-basal Albian }\end{array}$ & $\begin{array}{l}\text { [forma A]: basal horizontal } \\
\text { transverse section of a } \\
\text { complete theca [TS-Theca] } \\
\text { [forma B]: transverse-oblique } \\
\text { section of a nearly complete } \\
\text { theca [Obl/TS-Theca] } \\
\text { [forma C]: deeply crenulated } \\
\text { oblique-transverse section of a } \\
\text { nearly complete theca [T/OblS- } \\
\text { Theca] } \\
\text { Applinocrinus sp. }\end{array}$ & Barremian (?)-Aptian \\
\hline & $\begin{array}{l}\text { Pl. XXXI Fig. } 1 \\
\text { [no fig.] }\end{array}$ & $\begin{array}{c}\text { Globochaete alpina Lombard... } \\
\text { junto con Nannoconus sp. y } \\
\text { Microcalamoides diversus no } \\
\text { visibles... }\end{array}$ & $\begin{array}{c}\text { Cañón del Guaje } \\
\text { Sierra de Tamaulipas } \\
\text { Aptian }\end{array}$ & Applinocrinus sp. & Aptian \\
\hline & Pl. XXXI Fig. 3 & $\begin{array}{c}\text { Varias "esporas" de } \\
\text { Globochaete alpina adheridas a } \\
\text { un soporte }\end{array}$ & $\begin{array}{l}\text { Cañon del Chilpitin, Sierra de } \\
\text { la Gloria, Coahuila } \\
\text { Lower Cretaceous }\end{array}$ & $\begin{array}{c}\text { Transverse section of a radial } \\
\text { plate } \\
\text { [TS-Rad] } \\
\text { Applinocrinus sp. }\end{array}$ & lower Cretaceous \\
\hline \multirow{3}{*}{ Peck (1973) } & p. 95 & Applinocrinus n. gen. & & & \\
\hline & $\begin{array}{l}\text { p. } 97-98 \\
\text { Pl. 1, figs. 1-3, 6-12; Text- } \\
\text { figs. 1c-d }\end{array}$ & $\begin{array}{l}\text { Applinocrinus cretaceus } \\
\text { (Bather, 1924) }\end{array}$ & $\begin{array}{c}\text { Campanian } \\
\text { uppermost Taylor-lower } \\
\text { Navarro Fms } \\
\text { US Gulf Coast and Jamaica } \\
\text { Mendez Shale } \\
\text { ?Tamaulipas or ?Nuevo Leon, } \\
\text { Mx }\end{array}$ & & \\
\hline & $\begin{array}{l}\text { p. } 98, \\
\text { Text-figs. } 1 \mathrm{a}, \mathrm{b}, \\
\text { Pl. } 1 \text { figs. } 4-5\end{array}$ & $\begin{array}{l}\text { Applinocrinus texanus } \mathrm{n} . \\
\text { sp.[OD] }\end{array}$ & $\begin{array}{c}\text { Upper Taylor and Navarro } \\
\text { Fms } \\
\text { Texas and Jamaica }\end{array}$ & & $\begin{array}{l}\text { Uppermost Campanian- } \\
\text { Lower Maastrichtian } \\
\text { Texas, Florida } \\
\text { and Mississippi }\end{array}$ \\
\hline
\end{tabular}


Table 1. Correspondance between published roveacrinid taxa and their revised assignment (continuation).

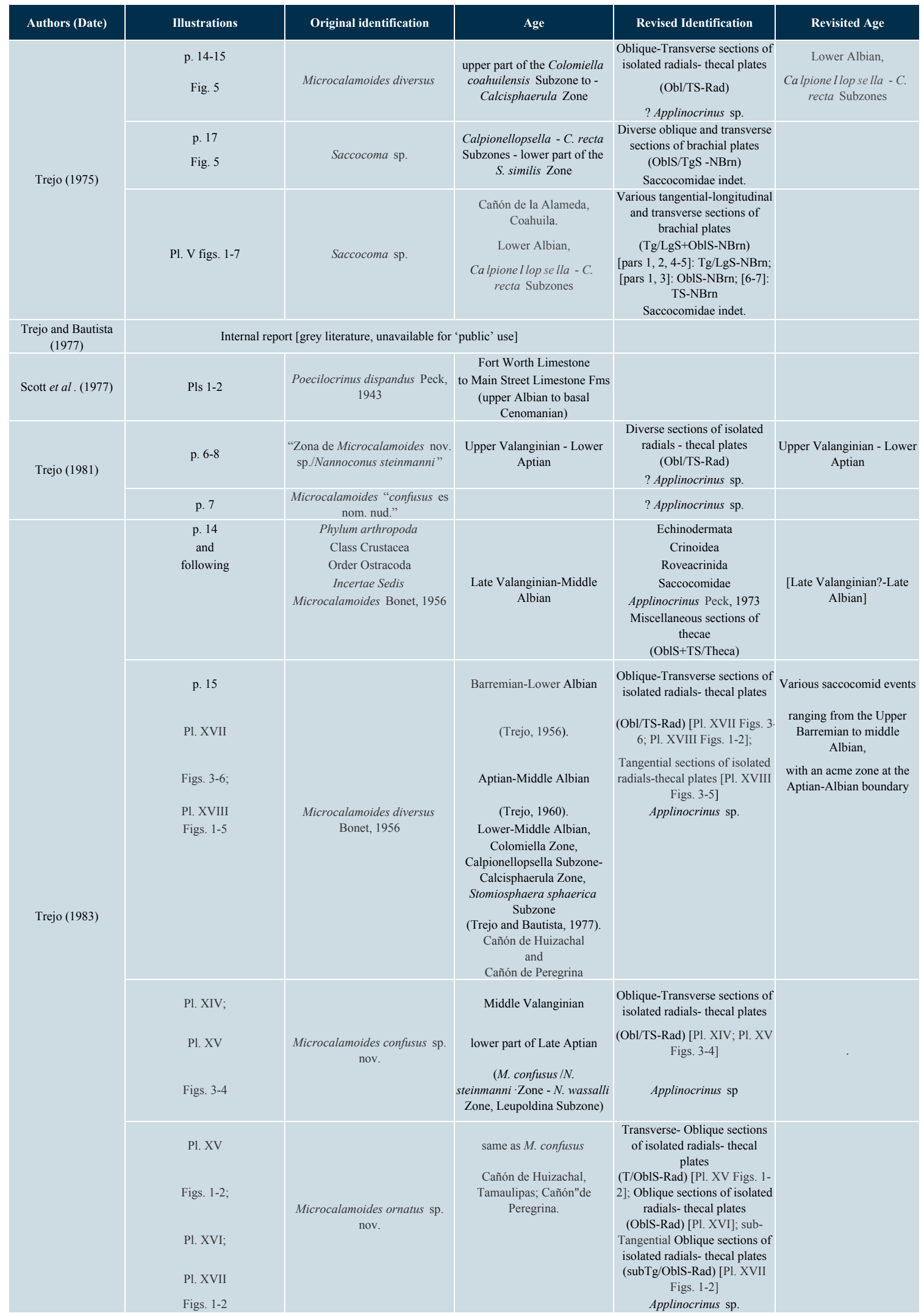


Table 1. Correspondance between published roveacrinid taxa and their revised assignment (continuation).

\begin{tabular}{|c|c|c|c|c|c|}
\hline Authors (Date) & Illustrations & Original identification & Age & Revised Identification & Revisited Age \\
\hline McNulty (1985) & No figure & $\begin{array}{c}\text { "Microcalamoides" mentioned } \\
\text { in the text }\end{array}$ & 'Lower Cretaceous' & $\begin{array}{l}\text { Most probably Transverse- } \\
\text { Oblique sections of isolated } \\
\text { plates or complete thecas } \\
\text { (T/OblS-Rad) } \\
\text { Applinocrinus sp. }\end{array}$ & $\begin{array}{l}\text { Most probably } \\
\text { "Lower Albian?" }\end{array}$ \\
\hline \multirow{7}{*}{$\begin{array}{c}\text { Longoria and } \\
\text { Monreal (1990) }\end{array}$} & p. 21: Fig. 7.2 & $\begin{array}{l}\text { Sample AR77-25. Biomicrite. } \\
\text { Unit III-33-IV-33. Planktonic } \\
\text { echinoderm Saccocoma, } \\
\text { ostracod fragments } \\
\text { (Microcalamoides diversus). }\end{array}$ & $\begin{array}{l}\text { uppermost Aptian Biozone K- } \\
\qquad 13 \\
\text { La Peña ?-Tamaulipas? Fms. }\end{array}$ & $\begin{array}{l}\text { Transverse-Longitudinal } \\
\text { section of an isolated radial } \\
\text { plate }(\mathrm{T} / \mathrm{LgS}-\mathrm{Rad}) \\
\text { Applinocrinus } \mathrm{sp} .\end{array}$ & Aptian-Albian boundary (?) \\
\hline & p. 21: Fig. 7.5 & $\begin{array}{l}\text { Sample AR75-35. Biomicrite. } \\
\text { Unit III-33-IV-33. Ostracod. }\end{array}$ & $\begin{array}{l}\text { uppermost Aptian Biozone K- } \\
13 \text { / upper Albian Biozone K- } \\
14 \text { / K-15 } \\
\text { La Peña ?-Tamaulipas? Fms. }\end{array}$ & $\begin{array}{l}\text { Transverse-Oblique section of } \\
\text { a complete theca (T/OblS-Rad) } \\
\text { Applinocrinus sp. }\end{array}$ & Aptian-Albian boundary \\
\hline & p. 21: Fig. 7.7 & $\begin{array}{l}\text { Sample AR84-50. Biomicrite. } \\
\text { Unit IV-35-V-35. Planktonic } \\
\text { foraminifer (Hedbergella } \\
\text { washitensis), calcisphaerulids } \\
\text { (Calcisphaerula innominata), } \\
\text { ostracod fragment } \\
\text { (Microcalamoides?). }\end{array}$ & $\begin{array}{l}\text { Upper Albian Biozone K- } \\
\text { 15/Cenomanian Biozone K-17 } \\
\text { Tamaulipas ?-Cuesta del } \\
\text { Cura ? Fms. }\end{array}$ & $\begin{array}{l}\text { Axial/sub-Oblique section of } \\
\text { an isolated radial plate (Ax/sub- } \\
\text { OblS-Rad) } \\
\text { Applinocrinus sp. }\end{array}$ & $\begin{array}{l}\text { upper Albian-lower } \\
\text { Cenomanian (?) }\end{array}$ \\
\hline & p. 21: Fig. 7.10 & $\begin{array}{c}\text { Sample AR68-25. Biomicrite. } \\
\text { Unit III-33-IV-33. Ostracod } \\
\text { shell fragment } \\
\text { (Microcalamoides diversus), } \\
\text { calcisphaerulids } \\
\text { (Calcisphaerula innominata). }\end{array}$ & La Peña ?-Tamaulipas ? Fms. & $\begin{array}{l}\text { Transverse Longitudinal } \\
\text { section of a isolated radial } \\
\text { plate }(\mathrm{T} / \mathrm{LgS}-\mathrm{Rad}) \\
\text { Applinocrinus } \mathrm{sp} .\end{array}$ & Aptian-Albian boundary (?) \\
\hline & p. 23: Fig. 8.21 & $\begin{array}{l}\text { Sample AR139-4. Biomicrite. } \\
\text { Unit IV. Planktonic } \\
\text { foraminífera, ostracods, } \\
\text { echinoderm fragments }\end{array}$ & $\begin{array}{l}\text { upper Albian Biozone K-15 } \\
\text { Tamaulipas ? Fm. }\end{array}$ & $\begin{array}{l}\text { Transverse Oblique section of } \\
\text { an isolated radial plate } \\
\text { (T/OblS-Rad) } \\
\text { Applinocrinus } \mathrm{sp} .\end{array}$ & Upper Albian (?) \\
\hline & p. 27 & $\begin{array}{l}\text { 5.3. ... Ostracods } \\
\text { (Microcalamoides) } \\
\text { 5.5. ...Pelagic echinoids } \\
\text { (saccocomids) }\end{array}$ & \multirow[b]{2}{*}{ Lower Cretaceous } & $\begin{array}{l}\text { [5.3.]: roveacrinoids } \\
\text { (Applinocrinus sp.) } \\
\text { [5.5.]: pelagic crinoids } \\
\text { (saccocomids) }\end{array}$ & $\begin{array}{c}\text { Lower } \\
\text { Cretaceous }\end{array}$ \\
\hline & No photograph & $\begin{array}{l}\text { "Microcalamoides" mentioned } \\
\text { in the text }\end{array}$ & & $\begin{array}{c}\text { Most likely Transverse- } \\
\text { Oblique sections of thecal } \\
\text { plates } \\
\text { (T/OblS-Rad) } \\
\text { Applinocrinus sp. }\end{array}$ & (Aptian-Albian) \\
\hline $\begin{array}{c}\text { Enos and Stephens } \\
\text { (1993) }\end{array}$ & $\begin{array}{c}\text { p. } 51 \\
\text { Fig. } 6 \\
\text { No photograph }\end{array}$ & Microcalamoides ornatus & $\begin{array}{l}\text { middle of the Morita Fm. } \\
\text { (upper) Aptian }\end{array}$ & $\begin{array}{l}\text { (?) Transverse- Oblique } \\
\text { sections of isolated radials- } \\
\text { thecal plates } \\
\text { (T/OblS-Rad) } \\
\text { Applinocrinus sp. }\end{array}$ & Upper Aptian (?) \\
\hline \multirow[t]{2}{*}{$\begin{array}{l}\text { Rosales-Dominguez } \\
\text { et al . (1995) }\end{array}$} & $\begin{array}{c}\text { Fig. } 6 \\
\text { No photograph }\end{array}$ & Microcalamoides ornatus & $\begin{array}{l}\text { Mural Limestone } \\
\text { Cullantrillo sequence } \\
\text { Lower Albian }\end{array}$ & $\begin{array}{l}\text { (?) Transverse- Oblique } \\
\text { sections of isolated radials- } \\
\text { thecal plates } \\
\text { (T/OblS-Rad) } \\
\text { Applinocrinus sp. }\end{array}$ & Lower Albian \\
\hline & p. 56 & Saccocoma sp. & $\begin{array}{c}\text { Cenomanian-Turonian } \\
\text { transition }\end{array}$ & Roveacrinidae indet. & $\mathrm{C} / \mathrm{T} \mathrm{B}$ \\
\hline \multirow{2}{*}{$\begin{array}{l}\text { Aguilera-Franco } \\
\text { (1995) }\end{array}$} & p. 70 Fig. 39 & $\begin{array}{c}\text { Litofacies } 11 \text { packstone de } \\
\text { equidermos y calciferúlidos, } \\
\text { UH } 94.38\end{array}$ & $\begin{array}{l}\text { Zotoltitlán section } \\
\text { Mexcala Fm. } \\
\text { Turonian }\end{array}$ & $\begin{array}{c}\text { Tangential section of a second } \\
\text { primibrachial plate } \\
(\mathrm{TgS}-\mathrm{IBr} 2) \\
\text { Roveacrinidae indet. }\end{array}$ & $\begin{array}{c}\text { C/T B } \\
\text { Tithonian }\end{array}$ \\
\hline & $\begin{array}{l}\text { p. } 24 \\
\text { Pl. I figs. } 3,5 \text {, } \\
\text { Pls. II-IV }\end{array}$ & $\begin{array}{c}\text { Saccocoma arachnoidea } \\
\text { (Brönnimann, 1955) }\end{array}$ & $\begin{array}{c}\text { Middle-late Tithonian } \\
\text { SE-Mexico }\end{array}$ & $\begin{array}{l}\text { Transverse and Oblique } \\
\text { sections of brachial plates } \\
\text { (Obl/TS-NBrn) } \\
\text { "Saccocoma"sp. }\end{array}$ & \\
\hline $\begin{array}{l}\text { Aguilera-Franco and } \\
\text { Franco-Navarrete } \\
\text { (1995) }\end{array}$ & $\begin{array}{l}\text { p. } 681 \\
\text { no fig. }\end{array}$ & Saccocoma sp. & $\begin{array}{c}\text { Cenomanian/Turonian B. } \\
\text { Guerrero-Morelos Platform, } \\
\text { Guerrero, S. Mexico }\end{array}$ & $\begin{array}{c}\text { Roveacrinidae indet. } \\
\text { [see subsequent publication: } \\
\text { 2001] }\end{array}$ & $\mathrm{C} / \mathrm{T} \mathrm{B}$ \\
\hline
\end{tabular}


Table 1. Correspondance between published roveacrinid taxa and their revised assignment (continuation).

\begin{tabular}{|c|c|c|c|c|c|}
\hline Authors (Date) & Illustrations & Original identification & Age & Revised Identification & Revisited Age \\
\hline $\begin{array}{c}\text { Aguilera-Franco et } \\
\text { al.(1997) }\end{array}$ & $\begin{array}{c}\text { p. } 245 \\
\text { p. } 250 \text { (fig. 13a) }\end{array}$ & $\begin{array}{l}\text { roveacrinids (Roveacrinus } \\
\text { geinitzi) }\end{array}$ & $\begin{array}{c}\text { Whiteinella archaeocretacea } \\
\text { PRZ }\end{array}$ & $\begin{array}{c}\text { Roveacrinidae indet. } \\
\text { [Roveacrinus "geinitzi"] }\end{array}$ & $\mathrm{C} / \mathrm{T} \mathrm{B}$ \\
\hline $\begin{array}{l}\text { Hernandez-Romano } \\
\text { et al } .(1997)\end{array}$ & Fig. 4 & Roveacrinus sp. & $\begin{array}{c}\text { Mexcala Fm. } \\
\text { Amacuzac section. } \\
\text { Whiteinella archaeocretacea } \\
\text { PRZ }\end{array}$ & Roveacrinus sp. & $\begin{array}{c}\text { C/T B } \\
\text { Lower Turonian } \\
(?)\end{array}$ \\
\hline \multirow{9}{*}{$\begin{array}{c}\text { Aguilera-Franco et } \\
\text { al. (2001) }\end{array}$} & Fig. 5 & Roveacrinus sp. & $\begin{array}{c}\text { Morelos Fm. } \\
\text { Las Tunas section. } \\
\text { Cenomanian } \\
\text { Whiteinella archaeocretacea } \\
\text { PRZ }\end{array}$ & Roveacrinus sp. & \multirow{4}{*}{$\begin{array}{c}\text { C/T B Lower Turonian (?) } \\
\text { Turonian H. helvetica TRZ } \\
\text { (?) }\end{array}$} \\
\hline & $\begin{array}{l}\text { Fig. } 5 \\
\text { Fig. } 6\end{array}$ & $\begin{array}{l}\text { Roveacrinus geinitzi } \\
\text { Roveacrinus cf. alatus }\end{array}$ & $\begin{array}{c}\text { Mexcala Fm. } \\
\text { Las Tunas section } \\
\text { Turonian } \\
\text { Whiteinella archaeocretacea } \\
\text { PRZ }\end{array}$ & $\begin{array}{l}\text { Roveacrinus "geinitzi" } \\
\text { Roveacrinus cf. alatus }\end{array}$ & \\
\hline & \multirow[t]{2}{*}{$\begin{array}{l}\text { Fig. } 5 \\
\text { Fig. } 6 \\
\text { Fig } 7\end{array}$} & Roveacrinus geinitzi & $\begin{array}{c}\text { Mexcala Fm. } \\
\text { Barranca del Tigre section } \\
\text { lower Turonian and } \\
\text { lower-middle Turonian } \\
\text { Whiteinella archaeocretacea } \\
\text { PRZ-H. helvetica TRZ pars }\end{array}$ & Roveacrinus "geinitzi" & \\
\hline & & Roveacrinus geinitzi & $\begin{array}{c}\text { Mexcala Fm. } \\
\text { Zototitlán section } \\
\text { Turonian }\end{array}$ & Roveacrinus "geinitzi" & \\
\hline & Fig. 11 & $\begin{array}{l}\text { B3. Increase in abundance of } \\
\text { calcisphaerulids, echinoids, } \\
\text { roveacrinoids and globigerinids } \\
\text { (hedbergellids and } \\
\text { heterohelicids) }\end{array}$ & $\begin{array}{l}\text { Guerrero-Morelos Basin } \\
\qquad \mathrm{C} / \mathrm{T}\end{array}$ & $\begin{array}{l}\text { Roveacrinida indet. } \\
\text { [Roveacrinidae }]\end{array}$ & $\begin{array}{l}\text { Uppermost } \\
\text { Cenomanian }\end{array}$ \\
\hline & Fig. 12(d) & Crinoids & $\begin{array}{c}\text { Las Tunas section } \\
\text { between B3 and B4 } \\
\text { sample } 28\end{array}$ & $\begin{array}{c}\text { Tangential oblique sections of } \\
\text { radial plates } \\
\text { (Tg/OblS-Rad) } \\
\text { Roveacrinidae indet. }\end{array}$ & $\begin{array}{l}\text { Uppermost } \\
\text { Cenomanian }\end{array}$ \\
\hline & Fig. 13(a) & Roveacrinids & $\begin{array}{c}\text { Las Tunas section } \\
\text { above B6 } \\
\text { (upper part of the Whiteinella } \\
\text { archaeocretacea } \text { PRZ) } \\
\text { sample } 36\end{array}$ & $\begin{array}{c}\text { Oblique sections of brachial } \\
\text { plates } \\
\text { (OblS-NBrn) } \\
\text { Roveacrinidae indet. }\end{array}$ & $\begin{array}{l}\text { Uppermost } \\
\text { Cenomanian }\end{array}$ \\
\hline & p. 205 & Microcalamoides sp. & $\begin{array}{c}\text { Morelos Fm. } \\
\text { Upper Albian- } \\
\text { Cenomanian/Turonian }\end{array}$ & $\begin{array}{c}\text { Most likely Transverse- } \\
\text { Oblique sections of thecal } \\
\text { plates } \\
\text { (T/OblS-Rad) } \\
\text { Applinocrinus sp. }\end{array}$ & $\begin{array}{c}\text { Morelos Fm. } \\
\text { [=Upper Tamaulipas Fm] } \\
\text { Upper Albian- } \\
\text { Cenomanian }\end{array}$ \\
\hline & Pl. 1 Fig. 10 & $\begin{array}{l}\text { Roveacrinus sp.RMCH aff. } \\
\text { rugosus , Las Tunas, NA96-28 }\end{array}$ & $\begin{array}{c}\text { Morelos Fm. } \\
\text { Upper Cenomanian } \\
\text { Whiteinella archaeocretacea } \\
\text { PRZ }\end{array}$ & $\begin{array}{c}\text { Roveacrinus aff. } R \text {. rugosus } \\
\text { Douglas, } 1908\end{array}$ & $\begin{array}{c}\text { Morelos Fm. } \\
\text { Upper Cenomanian } \\
\text { Archaeocretacea PRZ }\end{array}$ \\
\hline
\end{tabular}


Table 1. Correspondance between published roveacrinid taxa and their revised assignment (continuation).

\begin{tabular}{|c|c|c|c|c|c|}
\hline Authors (Date) & Illustrations & Original identification & Age & Revised Identification & Revisited Age \\
\hline \multirow{5}{*}{$\begin{array}{l}\text { Aguilera-Franco } \\
\text { (2003) }\end{array}$} & $\begin{array}{l}\text { Figs. } 4,6-7 \text {, } \\
\text { p. } 215 \\
\text { Fig. } 10\end{array}$ & Roveacrinus sp. & $\begin{array}{c}\text { Base of Cuautla Fm } \\
\text { [Figs. 6-7] } \\
\text { Upper Cenomanian/ } \\
\text { Lower Turonian } \\
\text { Whiteinella archaeocretacea } \\
\text { PRZ } \\
\text { Base of the Mexcala Fm. } \\
\text { [Fig. 10] }\end{array}$ & $\begin{array}{l}\text { Oblique and transverse sections } \\
\text { of proximal brachial plates } \\
\text { (T/Obl-NBrn) } \\
\text { Roveacrinus } \mathrm{sp} .\end{array}$ & $\begin{array}{l}\text { Upper Cenomanian- } \\
\text { Lower Turonian }\end{array}$ \\
\hline & $\begin{array}{l}\text { Figs. } 4,6-7 \\
\text { p. } 215\end{array}$ & Roveacrinus geinitzi & $\begin{array}{c}\text { Base of Cuautla Fm } \\
\text { Upper Cenomanian } \\
\text { Whiteinella archaeocretacea } \\
\text { PRZ }\end{array}$ & $\begin{array}{l}\text { Transverse sections of radial } \\
\text { plates and thecas } \\
\text { (TS-Rad) } \\
\text { Roveacrinus geinitzi }\end{array}$ & $\begin{array}{l}\text { Uppermost } \\
\text { Cenomanian } \\
\text { Top of the } \\
\text { Archaeocretacea } \\
\text { Zone } \\
\text { Lower Turonian }\end{array}$ \\
\hline & $\begin{array}{l}\text { Fig. } 4 \\
\text { p. } 215\end{array}$ & $R$. cf. alatus & $\begin{array}{c}\text { Upper part of the } \\
\text { Whiteinella archaeocretacea } \\
\text { PRZ }\end{array}$ & $\begin{array}{l}\text { Oblique and Transverse } \\
\text { sections of radial and thecal } \\
\text { plates } \\
\text { (T/OblS-Rad) } \\
\text { R. cf. alatus }\end{array}$ & $\begin{array}{c}\text { Uppermost } \\
\text { Cenomanian (?) } \\
\text { Top of the } \\
\text { Archaeocretacea } \\
\text { Zone [p. 215] } \\
\text { Cuautla Fm. } \\
\text { Lower Turonian } \\
\text { [Fig. 4] }\end{array}$ \\
\hline & $\begin{array}{l}\text { p. } 144 \text { (and following) } \\
\text { Tables 2-3 }\end{array}$ & roveacrinids & $\begin{array}{c}\text { Cuautla Fm, } \\
\text { Zototitlán Mb } \\
\text { Guerrero-Morelos Basin } \\
\text { late Cenomanian-Coniacian } \\
\text { extending beyond the } \\
\text { Whiteinella archaeocretacea } \\
\text { PRZ }\end{array}$ & Roveacrinidae indet. & $\mathrm{C} / \mathrm{T} \mathrm{B}$ \\
\hline & Fig. 8 & $\begin{array}{l}\text { Roveacrinus sp. cf. alatus } \\
\text { Roveacrinus geinitzi }\end{array}$ & $\begin{array}{c}\text { Cuautla Fm, } \\
\text { Zototitlán Mb } \\
\text { Guerrero-Morelos Basin } \\
\text { late Cenomanian-Coniacian } \\
\text { extending beyond the } \\
\text { Whiteinella archaeocretacea } \\
\text { PRZ } \\
\text { "Uppermost Cenomanian age, } \\
\text { top of } \text { R. cushmani zone" [in } \\
\text { the text] } \\
\text { Late Cenomanian, Rotalipora } \\
\text { cushmani zone (Unit B, } \\
\text { sample 1851) [as legend] } \\
\text { CSDP-drill core } \\
\text { Yaxcopoil-1 }\end{array}$ & $\begin{array}{l}\text { Roveacrinus sp. cf. alatus, } \\
\text { Roveacrinus } \text { cf. geinitzi }\end{array}$ & $\begin{array}{c}\text { C/T B } \\
\text { Latest Cenomanian } \\
\text { Top of Cushmani TRZ } \\
\text { CSDP-drill core } \\
\text { Yaxcopoil-1 }\end{array}$ \\
\hline \multirow{4}{*}{$\begin{array}{l}\text { Aguilera-Franco and } \\
\text { Hernández-Romano } \\
\text { (2004) }\end{array}$} & Fig. 13(D) & $\begin{array}{l}\text { Calcisphaerulid-roveacrinid-thin- } \\
\text { bivalve } \\
\text { shell packstone } \\
\text { (facies F1). } \\
\text { Las Tunas section, } \\
\text { sample NA96-30. }\end{array}$ & \multirow{4}{*}{$\begin{array}{l}\text { Cuautla Fm, Zototitlán Mb } \\
\text { Guerrero-Morelos Basin late } \\
\text { Cenomanian-Coniacian } \\
\text { extending beyond the } \\
\text { Whiteinella archaeocretacea } \\
\text { PRZ } \\
\text { "Uppermost Cenomanian age, } \\
\text { top of } \text { R. cushmani zone" [in } \\
\text { the text] Late Cenomanian, } \\
\text { Rotalipora cushmani zone } \\
\text { (Unit B, sample 1851) [as } \\
\text { legend] CSDP-drill core } \\
\text { Yaxcopoil-1 Around the } \\
\text { Aptian-Albian boundary (in } \\
\text { coll .) }\end{array}$} & $\begin{array}{c}\text { Tangential oblique sections of } \\
\text { brachial plates (Tg/OblS-NBrn) } \\
\text { Roveacrinidae indet. }\end{array}$ & \multirow{4}{*}{$\begin{array}{l}\text { C/T B Latest Cenomanian } \\
\text { Top of Cushmani TRZ } \\
\text { CSDP-drill core } \\
\text { Yaxcopoil-1 } \\
\text { Base of early Albian }\end{array}$} \\
\hline & p. 157 & $\begin{array}{l}\text { Roveacrinus sp., } \\
\text { Roveacrinus } \text { cf. geinitzi }\end{array}$ & & $\begin{array}{c}\text { Roveacrinus sp., } \\
\text { Roveacrinus } \text { cf. geinitzi }\end{array}$ & \\
\hline & Figure 31 & $\begin{array}{l}\text { « Rare pelagic crinoids » } \\
\text { (in the text) } \\
\text { « Planktic crinoid » } \\
\text { (as legend) }\end{array}$ & & $\begin{array}{c}\text { Slightly tilted oblique, } \\
\text { transverse section of a sub- } \\
\text { complete theca (sub-Obl/TS- } \\
\text { Theca) of Roveacrinus alatus } \\
\text { Douglas, } 1901\end{array}$ & \\
\hline & No figure & $\begin{array}{c}\text { "Microcalamoides" mentioned in } \\
\text { the text }\end{array}$ & & $\begin{array}{l}\text { Most likely Transverse- } \\
\text { Oblique sections of thecal } \\
\text { plates } \\
\text { (T/OblS-Rad) } \\
\text { Applinocrinus } \text { sp. }\end{array}$ & \\
\hline
\end{tabular}


Table 1. Correspondance between published roveacrinid taxa and their revised assignment (continuation).

\begin{tabular}{|c|c|c|c|c|c|}
\hline Authors (Date) & Illustrations & Original identification & Age & Revised Identification & Revisited Age \\
\hline \multirow{2}{*}{$\begin{array}{l}\text { Stinnesbeck et al } . \\
\text { (2004) }\end{array}$} & p. 1044 & "rare pelagic crinoids" & & Roveacrinidae & $\begin{array}{c}\text { Miscellaneous "early" } \\
\text { C/TBE } \\
\text { Most likely the Roveacrinus } \\
\text { beds of the Plenus Marls }\end{array}$ \\
\hline & Fig. 3.1. & "Planktic crinoid" & $\begin{array}{l}\text { Late Cenomanian Rotalipora } \\
\text { cushmani zone (Unit B, } \\
\text { sample 1851) }\end{array}$ & $\begin{array}{c}\text { Oblique/Tangential section of a } \\
\text { sub-complete theca (Obl/TgS- } \\
\text { Theca) } \\
\text { Roveacrinus alatus Douglas }\end{array}$ & \\
\hline $\begin{array}{l}\text { Gréselle et al . (2009, } \\
\text { 2010) }\end{array}$ & $\begin{array}{l}\text { in coll. } \\
\text { No photograph }\end{array}$ & Roveacrinids & $\begin{array}{l}\text { Latest Cenomanian } \\
\text { Archaeocretacea PRZ } \\
\text { Soyatal Formation } \\
\text { (Sample C13) }\end{array}$ & $\begin{array}{c}\text { Roveacrinidae indet. } \\
(\mathrm{Tg} / \mathrm{LS}-\mathrm{NBrn})\end{array}$ & $\begin{array}{l}\text { Archaeocretacea PRZ } \\
\text { Latest Cenomanian }\end{array}$ \\
\hline \multirow{3}{*}{$\begin{array}{l}\text { Núñez-Useche and } \\
\text { Barragán (2012) }\end{array}$} & Fig. 2 (legend) & Saccocomids & $\begin{array}{c}\text { MA-15 } \\
\text { La Peña Formation }\end{array}$ & $\begin{array}{l}\text { Oblique section of a distal } \\
\text { brachial plate } \\
\text { (OblS-NBrn) } \\
\text { Roveacrinidae indet. }\end{array}$ & $\begin{array}{c}\text { Uppermost } \\
\text { Cenomanian (?) } \\
\text { Base of the } \\
\text { Whiteinella } \\
\text { archaeocretacea Zone }\end{array}$ \\
\hline & p. 209,210 & (?) Crinoids & $\begin{array}{c}\text { MA-14 [Crinoids] } \\
\text { "MA-15" [no mention] }\end{array}$ & Roveacrinida & $\begin{array}{l}\text { Top of La Peña Fm - Base } \\
\text { of Upper Tamaulipas Fm }\end{array}$ \\
\hline & $\begin{array}{l}\text { Figs. } 7 \mathrm{a}, 7 \mathrm{~b} \\
\text { p. } 210\end{array}$ & $\begin{array}{l}\text { "MA-17: ...microcalamoids } \\
\text { (Figure 7a-7b)" } \\
\text { "MA-18: ...microcalamoids" } \\
\text { (p. 211) } \\
\text { Probably some 'crinoids' } \\
\text { reported in the text, some other } \\
\text { confused with ophuroid plates }\end{array}$ & $\begin{array}{c}\text { Upper Tamaulipas Formation } \\
\text { Lower Albian }\end{array}$ & $\begin{array}{l}\text { Rather proximal brachial plates } \\
\text { of stem crinoids [Figures 7a- } \\
\text { 7b], and with some caution } \\
\text { most probably Transverse- } \\
\text { Oblique sections of thecal } \\
\text { plates (T/OblS-Rad) } \\
\text { Saccocomidae indet. }\end{array}$ & Early Albian \\
\hline Omaña et al . (2014) & $\begin{array}{l}\text { p. } 32 \\
\text { p. } 34 \text { Fig. } 5 \text { h, i }\end{array}$ & Roveacrinids & $\begin{array}{l}\text { Latest Cenomanian } \\
\text { Archaeocretacea PRZ } \\
\text { Soyatal Formation } \\
\text { (Sample C13) }\end{array}$ & $\begin{array}{c}\text { Roveacrinidae indet. } \\
(\mathrm{Ax} / \mathrm{LgS}-\mathrm{IBr} 2) \\
\text { [Possible ophiuroid plate }]\end{array}$ & $\begin{array}{l}\text { Archaeocretacea PRZ } \\
\text { Latest Cenomanian }\end{array}$ \\
\hline \multirow{5}{*}{$\begin{array}{l}\text { Buitron and Omaña } \\
\text { (2014) }\end{array}$} & $\begin{array}{l}\text { p. } 20 \\
\text { Fig. } 3 a, d\end{array}$ & $\begin{array}{l}\text { Poecilocrinus dispandus } \\
\text { elongatus } \text { Peck, } 1943\end{array}$ & $\begin{array}{l}\text { Lower Turonian Platform, } \\
\text { Valles-San Luis Potosí, } \\
\text { Mexico: }\end{array}$ & $\begin{array}{c}\text { a: oblique section of a distal } \\
\text { brachial plate } \\
\text { [TgS-NBrn] } \\
\text { Roveacrinidae indet. } \\
\text { d: tangential section of a distal } \\
\text { brachial plate } \\
\text { [TgS-NBrn] } \\
\text { Roveacrinidae indet. }\end{array}$ & $\begin{array}{c}\text { Uppermost } \\
\text { Cenomanian (?) } \\
\text { Base of the } \\
\text { Whiteinella } \\
\text { archaeocretacea Zone }\end{array}$ \\
\hline & Fig. 3b, c, e & $\begin{array}{l}\text { Roveacrinus geinitzi Schneider, } \\
1989\end{array}$ & $\begin{array}{c}\text { Lower Turonian Platform, } \\
\text { Valles-San Luis Potosí, } \\
\text { Mexico: } \\
\text { Guassa Fm. } \\
\text { San Vicente Mb. } \\
\text { Upper Jurassic } \\
\text { Tithonian }\end{array}$ & $\begin{array}{l}\text { b: possible tangential section of } \\
\text { a radial plate [TgS-Rad] } \\
\text { ?Roveacrinus sp.; } \\
\text { c: tangential section of a distal } \\
\text { brachial plate } \\
\text { [TgS-NBrn] } \\
\text { Roveacrinidae indet. } \\
\text { [e: possibly an ophiuroid plate } \\
\text { section]. }\end{array}$ & $\begin{array}{c}\text { Uppermost } \\
\text { Cenomanian (?) } \\
\text { Base of the } \\
\text { Whiteinella } \\
\text { archaeocretacea Zone } \\
\text { San Vicente Mb. } \\
\text { (Guassa Fm.) } \\
\text { uppermost Jurassic } \\
\text { (Tithonian) } \\
\text { Below the } \mathrm{J} / \mathrm{K} \text { boundary }\end{array}$ \\
\hline & $\begin{array}{l}\text { p. } 20 \\
\text { Fig. } 3 f\end{array}$ & Roveacrinus sp. & \multirow{3}{*}{$\begin{array}{l}\text { Lower Turonian Platform, } \\
\text { Valles-San Luis Potosí, } \\
\text { Mexico: Guassa Fm. San } \\
\text { Vicente Mb. Upper Jurassic } \\
\text { Tithonian Guassa Fm. San } \\
\text { Vicente Mb. Upper Jurassic } \\
\text { Tithonian Cenomaniano } \\
\text { superior-Turoniano inferior (in } \\
\text { text, p.18) Cenomaniano- } \\
\text { Touriano [sic, in Fig. 2] Zona } \\
\text { Whiteinella archeocretacea } \\
\text { Formación Soyatal }\end{array}$} & $\begin{array}{c}\text { Possible oblique tangential } \\
\text { section of a second } \\
\text { primibrachial or an isolated } \\
\text { radial plate } \\
\text { (Tg/OblS-IBr2/Rad) } \\
\text { Roveacrinidae indet. }\end{array}$ & \multirow{3}{*}{$\begin{array}{l}\text { Uppermost Cenomanian (?) } \\
\text { Base of the Whiteinella } \\
\text { archaeocretacea Zone San } \\
\text { Vicente Mb. (Guassa Fm.) } \\
\text { uppermost Jurassic } \\
\text { (Tithonian) Below the } \mathrm{J} / \mathrm{K} \\
\text { boundary San Vicente Mb. } \\
\text { (Guassa Fm.) uppermost } \\
\text { Jurassic (Tithonian) Below } \\
\text { the } \mathrm{J} / \mathrm{K} \text { boundary } \\
\text { Archaeocretacea PRZ } \\
\text { Latest Cenomanian }\end{array}$} \\
\hline & p. 434 & "saccocomids" and "filaments" & & $\begin{array}{c}\text { Various sections } \\
\text { ['saccocomids'] } \\
\text { (T/Obl-NBrn) } \\
\text { and longitudinal sections } \\
\text { (LgS-NBrn) } \\
\text { of brachial plates ['filaments'] } \\
\text { of Saccocomidae indet. }\end{array}$ & \\
\hline & $\begin{array}{c}\text { Figure } 2 \\
\text { (second microfacies picture } \\
\text { from the top) }\end{array}$ & $\begin{array}{c}\text { "roveacrinidos" [comment in } \\
\text { text, p. 18] }\end{array}$ & & $\begin{array}{c}\text { Oblique section of a brachial } \\
\text { plate } \\
\text { (OblS-NBrn) } \\
\text { Roveacrinidae indet. }\end{array}$ & \\
\hline
\end{tabular}


Table 1. Correspondance between published roveacrinid taxa and their revised assignment (continuation).

\begin{tabular}{|c|c|c|c|c|c|}
\hline Authors (Date) & Illustrations & Original identification & Age & Revised Identification & Revisited Age \\
\hline \multirow{3}{*}{$\begin{array}{l}\text { López-Martínez et } \\
\text { al. (2014) }\end{array}$} & Fig. 3E & $\begin{array}{l}\text { "Highly disarticulated and } \\
\text { densely packed Soccocomids" }\end{array}$ & \multirow{3}{*}{$\begin{array}{l}\text { Guassa Fm. San Vicente Mb. } \\
\text { Upper Jurassic Tithonian } \\
\text { Cenomaniano superior- } \\
\text { Turoniano inferior (in text, } \\
\text { p.18) Cenomaniano-Touriano } \\
\text { [sic, in Fig. 2] Zona } \\
\text { Whiteinella archeocretacea } \\
\text { Formación Soyatal lower } \\
\text { Turonian Platform Valles-San } \\
\text { Luis Potosí }\end{array}$} & $\begin{array}{l}\text { Transverse sections of second } \\
\text { primibrachial plates }\end{array}$ & \multirow{3}{*}{$\begin{array}{l}\text { San Vicente Mb. (Guassa } \\
\text { Fm.) uppermost Jurassic } \\
\text { (Tithonian) Below the J/K } \\
\text { boundary Archaeocretacea } \\
\text { PRZ Latest Cenomanian } \\
\text { Archaeocretacea PRZ } \\
\text { Latest Cenomanian } \\
\text { Cerratescens cerratescens } \\
\text { Zone [from Scott et al. } \\
\text { 2016] (upper Albian) }\end{array}$} \\
\hline & p. $434-436,439$ & Saccocoma & & $\begin{array}{c}\text { Rather } \\
\text { "Saccocoma" auct. }\end{array}$ & \\
\hline & Fig. 3A & $\begin{array}{l}\text { Tangential section of the theca } \\
\text { of Poecilocrinus dispandus } \\
\text { elongatus } \text { Peck, } 1943\end{array}$ & & $\begin{array}{l}\text { Tangential longitudinal section } \\
\text { of a median brachial (Tg/LS- } \\
\text { NBrn) of Roveacrinidae indet. } \\
\text { (comparable to } \text { R. alatus } \\
\text { Douglas or } \text { R. spinosus } \text { Peck) }\end{array}$ & \\
\hline \multirow{6}{*}{$\begin{array}{l}\text { Buitron and Omaña } \\
\text { (2015) }\end{array}$} & Fig. 3B & $\begin{array}{l}\text { Longitudinal section of the theca } \\
\text { of Roveacrinus geinitzi } \\
\text { Schneider, } 1989\end{array}$ & \multirow{6}{*}{$\begin{array}{l}\text { lower Turonian Platform } \\
\text { Valles-San Luis Potosí }\end{array}$} & $\begin{array}{l}\text { Longitudinal section of a } \\
\text { brachial (LS-NBrn) of } \\
\text { Roveacrinidae indet. }\end{array}$ & \multirow{6}{*}{$\begin{array}{l}\text { Archaeocretacea PRZ } \\
\text { Latest Cenomanian } \\
\text { Cerratescens cerratescens } \\
\text { Zone [from Scott } \text { et al., } \\
\text { 2016] (upper Albian) }\end{array}$} \\
\hline & $\begin{array}{l}\text { Fig. 3C } \\
\text { [=Fig. } 5 \mathrm{~h}, \\
\text { Omaña et al. } \\
\text { 2014] }\end{array}$ & $\begin{array}{l}\text { Longitudinal section of the theca } \\
\text { of Roveacrinus geinitzi } \\
\text { Schneider, } 1989\end{array}$ & & $\begin{array}{l}\text { Tangential longitudinal section } \\
\text { of a proximal brachial (Tg/LS- } \\
\text { NBrn) of Roveacrinidae indet. } \\
\text { (comparable to } R \text {. alatus } \\
\text { Douglas or } R \text {. spinosus Peck) }\end{array}$ & \\
\hline & Fig. 3D & $\begin{array}{l}\text { Longitudinal section of the theca } \\
\text { of Poecilocrinus dispandus } \\
\text { elongatus } \text { Peck, } 1943\end{array}$ & & $\begin{array}{l}\text { Tangential longitudinal section } \\
\text { of a first primibrachial }(\mathrm{Tg} / \mathrm{LS}- \\
\mathrm{IBr} 1) \text { of Roveacrinidae indet. }\end{array}$ & \\
\hline & $\begin{array}{c}\text { Fig. } 3 \mathrm{E} \\
\text { [=Fig. } 5 \mathrm{i}, \\
\text { Omaña et al. } 2014]\end{array}$ & $\begin{array}{l}\text { Longitudinal sections of the } \\
\text { theca of Roveacrinus geinitzi } \\
\text { Schneider, } 1989\end{array}$ & & $\begin{array}{c}\text { Possible axial longitudinal } \\
\text { section of a second } \\
\text { primibrachial of Roveacrinidae } \\
\text { indet. } \\
\text { or } \\
\text { Axial longitudinal section of } \\
\text { an ophiuroid plate }\end{array}$ & \\
\hline & Fig. $3 \mathrm{~F}$ & $\begin{array}{l}\text { Longitudinal section of the theca } \\
\text { of Roveacrinus sp. }\end{array}$ & & $\begin{array}{c}\text { Possible sub-Tangential } \\
\text { section of a radial plate } \\
\text {-around the articular facet- } \\
\text { (TgS-Rad) of Roveacrinus sp. }\end{array}$ & \\
\hline & Figs. 4-8 & $\begin{array}{c}\text { Poecilocrinus latealatus (Peck, } \\
\text { 1943) }\end{array}$ & & & \\
\hline \multirow{9}{*}{ Hess (2015) } & Figs. 9-11 & $\begin{array}{l}\text { Roveacrinus pyramidalis Peck, } \\
\qquad 1943\end{array}$ & $\begin{array}{l}\text { Top of the upper Duck Creek } \\
\text { Fm., Del Rio Clay Fm., } \\
\text { Mortoniceras rostratum Zone } \\
\text { [Heterohelix reussi Zone] } \\
\text { (upper Albian) }\end{array}$ & & \\
\hline & Figs. $12-13$ & $\begin{array}{l}\text { Orthogonocrinus apertus Peck, } \\
1943\end{array}$ & $\begin{array}{l}\text { Top of the upper Duck Creek } \\
\text { Fm., Del Rio Clay Fm., } \\
\text { Mortoniceras rostratum Zone } \\
\text { [Heterohelix reussi Zone] } \\
\text { (upper Albian) Del Rio Fm. } \\
\text { (lower Cenomanian) }\end{array}$ & & $\begin{array}{c}\text { Cerratescens cerratescens } \\
\text { Zone } \\
\text { [from Scott } \text { et al ., 2016] } \\
\text { (upper Albian) } \\
\text { Del Rio Clay Fm. } \\
\text { (lower Cenomanian) }\end{array}$ \\
\hline & $\begin{array}{l}\text { Figs. 12h, } \\
\text { ?13a, d }\end{array}$ & $\begin{array}{c}\text { Roveacrinus peracutus (Peck, } \\
1943 \text { ) }\end{array}$ & \multirow{4}{*}{$\begin{array}{l}\text { Top of the upper Duck Creek } \\
\text { Fm., Del Rio Clay Fm., } \\
\text { Mortoniceras rostratum Zone } \\
\text { [Heterohelix reussi Zone] } \\
\text { (upper Albian) Del Rio Fm. } \\
\text { (lower Cenomanian) Del Rio } \\
\text { Fm. (lower Cenomanian) } \\
\text { Taylor-Navarro Fms. } \\
\text { Uppermost Campanian - } \\
\text { Lower Maastrichtian }\end{array}$} & & \multirow{4}{*}{$\begin{array}{l}\text { Cerratescens cerratescens } \\
\text { Zone [from Scott et al., } \\
\text { 2016] (upper Albian) Del } \\
\text { Rio Clay Fm. (lower } \\
\text { Cenomanian) Del Rio Clay } \\
\text { Fm. (lower Cenomanian) }\end{array}$} \\
\hline & $\begin{array}{l}\text { Figs. } 14 \mathrm{~d}, \mathrm{p}, \mathrm{t}, \\
? 15 \mathrm{a}, \mathrm{b}\end{array}$ & $\begin{array}{l}\text { Roveacrinus alatus Douglas, } \\
1908\end{array}$ & & & \\
\hline & $\begin{array}{l}\text { Figs. 14a-c, } \\
\text { e-o, q-s, } \\
15 c-w\end{array}$ & $\begin{array}{c}\text { Roveacrinus spinosus Peck, } \\
1943\end{array}$ & & & \\
\hline & Fig. 17 & $\begin{array}{c}\text { Roveacrinus peracutus (Peck, } \\
1943 \text { ) }\end{array}$ & & & \\
\hline & $\begin{array}{l}\text { Figs. 6D-E, } \\
\text { 7D-E, H-K }\end{array}$ & $\begin{array}{l}\text { Applinocrinus texanus } \\
\text { Peck, } 1973\end{array}$ & \multirow{3}{*}{$\begin{array}{c}\text { Del Rio Fm.(lower } \\
\text { Cenomanian) Taylor-Navarro } \\
\text { Fms. Uppermost Campanian - } \\
\text { Lower Maastrichtian Prairie } \\
\text { Bluff Chalk Fm. Upper } \\
\text { Maastrichtian Mississippi }\end{array}$} & & \multirow{3}{*}{$\begin{array}{l}\text { Del Rio Clay Fm. (lower } \\
\text { Cenomanian) }\end{array}$} \\
\hline & $\begin{array}{l}\text { Figs. 6C, G, } \\
\text { 7B-C, F-G }\end{array}$ & $\begin{array}{l}\text { Applinocrinus russelli } \\
\text { n. sp. [OD] }\end{array}$ & & & \\
\hline & $\begin{array}{l}\text { Figs. 5E, G-I, } \\
6 \mathrm{~A}, 7 \mathrm{~L}-\mathrm{Q}, \mathrm{T}\end{array}$ & $\begin{array}{l}\text { Sagittacrinus torpedo } \\
\text { n. gen. n. sp. [OD] }\end{array}$ & & & \\
\hline \multirow{2}{*}{ Gale (2016) } & Figs. 9L, P & $\begin{array}{l}\text { Jakeocrinus ellisensis } \\
\text { n. gen. n. sp. [OD] }\end{array}$ & $\begin{array}{c}\text { Taylor Fm. } \\
\text { Lower Campanian } \\
\text { Texas }\end{array}$ & & \\
\hline & Figs. $12 \mathrm{M}-\mathrm{O}$ & Platelicrinus sp. & $\begin{array}{c}\text { Taylor Fm. } \\
\text { Lower Campanian } \\
\text { Texas }\end{array}$ & & \\
\hline $\begin{array}{l}\text { Monier } e t \\
\text { al. }(2017 \mathrm{a}, \mathrm{b})\end{array}$ & Figs. 4A-L & $\begin{array}{l}\text { Diverse sections of brachial and } \\
\text { thecal plates of Roveacrinida, } \\
\text { Saccocomidae }\end{array}$ & $\begin{array}{c}\text { Albian } \\
\text { Sierra Azul, Cuenca de } \\
\text { Sabinas [Coahuila, Mx] }\end{array}$ & $\begin{array}{l}\text { Full description in prog. } \\
\text { (to be published elsewhere) }\end{array}$ & \\
\hline
\end{tabular}




\section{Appendix C}

Re-interpretation of previously illustrated roveacrinids.

A. Applinocrinus sp. - isolated radial - (T/LgS-Rad), Aptian-Albian boundary (?) (La Peña?-Tamaulipas

? Fms.) [sub Microcalamoides diversus, figure 7.2 in Longoria and Monreal, 1991: 21].

B. Applinocrinus sp. - complete theca - (T/OblSRad), Aptian-Albian boundary (?) (La Peña ?-Tamaulipas ? Fms.) [sub Ostracod, figure 7.5 in Longoria and Monreal, 1991: 21].

C. Applinocrinus sp. - isolated radial - (Ax/subOblS-Rad), Upper Albian-lower Cenomanian (?) (Tamaulipas ?-Cuesta del Cura ? Fms.) [sub Microcalamoides?, figure 7.7 in Longoria and Monreal, 1991 21].

D. Applinocrinus sp. - isolated radial - (T/OblSRad), Upper Albian (?) (Tamaulipas ? Fm.) [sub echinoderm fragments, figure 8.21 in Longoria and Monreal, 1991: 23].

E. Roveacrinus alatus Douglas - sub-complete theca - (Obl/TgS-Theca), Uppermost Cenomanian, top of the Cushmani Zone (ZoneYaxcopoil-1 drill site, southwest Merida) [sub 'Planktic crinoid' ex Stinnesbeck et al., 2004 (figure 3.1 in Stinnesbeck et al., 2004)].

F. Saccocomidae indet. - thecal plates - (T/OblSRad) with some caution, Lower Albian (La Peña and Upper Tamaulipas Fms.) [Roveacrinids $e x$ Núñez-Useche and Barragán, 2012 (figure 7a, b in Núñez-Useche and Barragán, 2012)].

G. Roveacrinidae indet. - distal brachial plate (OblS-NBrn), Uppermost Cenomanian (?), Base of the Whiteinella archaeocretacea Zone [without legend ex Omaña et al., 2014 (figure 2 in Omaña et al., 2014; second microfacies picture from top)].

I. Roveacrinidae indet. (Ax/LgS-IBr2) [Possible ophiuroid plate], Uppermost Cenomanian (?), Base of the Whiteinella archaeocretacea Zone (Soyatal Fm.) [Roveacrinids ex Omaña et al., 2014 (figure 5h, i in Omaña et al., 2014)].

J. Roveacrinidae indet. (TgS-NBrn), Base of the Whiteinella archaeocretacea Zone (Uppermost Cenomanian ?), Valles-San Luis Potosí [non Poecilocrinus dispandus elongatus Peck, 1943; ex
Buitrón-Sánchez and Omaña-Pulido, 2015 (figure 3a in Buitrón-Sánchez and Omaña-Pulido, 2015: 20)].

K. Roveacrinidae indet. (TgS-NBrn), Base of the Whiteinella archaeocretacea Zone (Uppermost Cenomanian ?), Valles-San Luis Potosí [non Poecilocrinus dispanduselongatus Peck, 1943; ex Buitrón-Sánchez and Omaña-Pulido, 2015 (figure 3d in Buitrón-Sánchez and Omaña-Pulido, 2015: 20)].

L.? Roveacrinus sp. (TgS-Rad), Base of the Whiteinella archaeocretacea Zone (Uppermost Cenomanian ?), San Vicente Mb. (Guassa Fm.), Valles-San Luis Potosí [non Roveacrinus geinitzi Schneider, 1989; ex Buitrón-Sánchez and Omaña-Pulido, 2014 (figure 3b in Buitrón-Sánchez and Omaña-Pulido, 2014: 20)].

M. Roveacrinidae indet. (TgS-NBrn), Base of the Whiteinella archaeocretacea Zone (Uppermost Cenomanian ?), San Vicente Mb. (Guassa Fm.), Valles-San Luis Potosí [non Roveacrinus geinitzi Schneider, 1989; ex Buitrón-Sánchez and OmañaPulido, 2014 (figure 3c in Buitrón-Sánchez and Omaña-Pulido, 2014: 20)].

N. Roveacrinidae indet. (Tg/OblS-IBr2/ Rad), Base of the Whiteinella archaeocretacea Zone (Uppermost Cenomanian ?), San Vicente Mb. (Guassa Fm.), Valles-San Luis Potosí [non Roveacrinus sp.; ex Buitrón-Sánchez and OmañaPulido, 2014 (figure 3f in Buitrón-Sánchez and Omaña-Pulido, 2014: 20)].

O. Roveacrinidae indet. (OblS-NBrn), Tithonian below the J/K boundary - Archaeocretacea PRZ (Latest Cenomanian), Soyatal Fm. [non roveacrinidos (comment in text, p. 18); ex Buitrón-Sánchez and Omaña-Pulido, 2014 (figure 2 in BuitrónSánchez and Omaña-Pulido, 2014 (second microfacies picture from the top)].

P. Roveacrinida indet. (TS-IBr2), Tithonian below the J/K boundary - Archaeocretacea PRZ (Latest Cenomanian), Soyatal Fm. [non Highly disarticulated and densely packed Soccocomids; $e x$ 
López-Martínez et al., 2014 (figure 3E in LópezMartínez et al., 2014)].

Q. Roveacrinidae indet. (Tg/LS-NBrn), Archaeocretacea PRZ (Latest Cenomanian), Valles-San Luis Potosí Platform [non Tangential section of the theca of Poecilocrinus dispandus elongatus Peck, 1943; ex Buitrón-Sánchez and OmañaPulido, 2015 (figure 3A in Buitrón-Sánchez and
Omaña-Pulido, 2015)].

R. Roveacrinidae indet. (LS-NBrn), Archaeocretacea PRZ (Latest Cenomanian), Valles-San Luis Potosí Platform [non Longitudinal section of the theca of Roveacrinus geinitzi Schneider, 1989; ex Buitrón-Sánchez and Omaña-Pulido, 2015 (figure 3B in Buitrón-Sánchez and OmañaPulido, 2015)]. 